\title{
MINERĀLO SAISTVIELU PĒTĪJUMI SILIKĀTU MATERIĀLU INSTITŪTĀ
}

\author{
JANĪNA SĒTIN, ${ }^{1^{*}}$, INNA JUHN̦EVIČÁ ${ }^{2}$, \\ JĀNIS BARONIN̦Š ${ }^{3}$, LIENE GULBE ${ }^{4}$ \\ 1,2,4 Silikātu materiālu institūts, Rīgas Tehniskā universitāte, Latvija, \\ ${ }^{3}$ Department of Mechanical and Industrial Engineering, \\ Tallinn University of Technology, Estonia
}

Kopsavilkums. Parādīti pēdējās desmitgades pētījumi minerālo saistvielu jomā. Pētīta dažādu aktīvo ḳīmisko piedevu ietekme uz betona struktūru, mehāniskajām un fizikālajām īpašībām. Novērtēta iegūto betonu korozijas izturība pret sulfātu sālu šksīdumiem. Pētīta dažādu rūpniecisko blakus produktu - pelnu - kā pucolānu piedevas ietekme uz betona īpašībām.

Atslēgas vārdi - saistvielas, betons, pucolāna piedevas, pelni, betona korozija.

\section{Ievads}

Javu saistvielas un to izmantošanas iespējas Silikātu materiālu institūtā un katedrā ir pētītas kopš to dibināšanas.

Javu saistvielas ir attīstījušās līdz ar mūsu civilizāciju. Ievērojams progress iezīmējās saistībā ar hidrauliskās saistvielas - cementa - ražošanu. Cements ir hidrauliska saistviela, un šis termins tiek lietots gan attiecībā uz dabiskas izcelsmes saistvielu, gan arī attiecībā uz mākslīgi veidotu saistvielu. Izplatītākais un nozīmīgākais mākslīgi veidota cementa paveids ir portlandcements [1], [2].

Cements ir viens no visplašāk izmantotajiem celtniecības materiāliem pasaulē un ir arī viena no galvenajām izejvielām otra pasaulē patērētākā materiāla - betona - ražošanā. Attīstoties celtniecības nozarei, ir

* Korespondējošais autors.

E-pasts: janina.setina@rtu.lv 
attīstījušies arī celtniecības materiāli, tajā skaitā cements. Pēdējos gados arvien vairāk tiek meklētas dažādas piedevas cementam, kas spētu uzlabot cementa izstrādājumu īpašības. N,emot vērā mūsdienās aktuālo jautājumu par iespējām samazināt $\mathrm{CO}_{2}$ emisijas, tiek meklēti materiāli, kas daḷeji varētu aizstāt cementu, jo cementa ražošanas laikā rodas aptuveni 5 \% no kopējiem pasaules $\mathrm{CO}_{2}$ izmešiem. Šādi materiāli var būt, piemēram, pucolāni [3]-[6].

Pucolāni ir aktīvo minerālu $\left(\mathrm{SiO}_{2}, \mathrm{Al}_{2} \mathrm{O}_{3}\right)$ saturoši materiāli, kurus var izmantot kā daḷejus cementa aizstājējus. Šiem materiāliem pašiem par sevi nepiemīt cementējošās īpašības (vai to ir nedaudz), bet smalki samaltā formā mitruma klātbūtnē (normālā temperatūrā) tie ir k,īmiski aktīvi un reagè ar kalcija hidroksīdu, veidojot savienojumus ar cementējošām īpašībām [7]-[9].

Arheologiiskie atklājumi parāda, ka pucolānu pielietošana kā neorganiska javu saistviela kopā ar apdedzinātiem kaļ̦iem sākusies jau antīkajā pasaulē. Daudz plašāk pucolānu piedevas sāka izmantot romieši dažādu ēku un pieminekḷu celtniecībā. 20. gadsimtā dal̦ēja cementa aizstāšana ar pucolāniem ir kluvusi par ierastu praksi.

Pēdējās desmitgadēs ir palielinājusies zinātnieku interese par pucolānu pielietošanas iespējām. Pucolānu piedevu pētījumus izraisījušas salīdzinoši dārgās cementa ražošanas izmaksas un ar to saistītie piesārn,ojumi, celtniecības nozares attīstība un nepieciešamība pēc kvalitatīviem, izturīgiem materiāliem.

Īpaši aktuāla pucolānu piedevu izmantošana ir tad, ja pucolāni veidojas kā blakusprodukti rūpnieciskajā ražošanā, piemēram, vieglie pelni, domnas krāsns izdedži, mikrosilika [9]-[10]. Šādi, dal̦ēji aizstājot cementu, tiek samazināts ne tikai cementa patēriņš un tā ražošanā radītais piesārṇojums, bet arī tiek risināta atkritumu deponēšana un būtiski tiek samazinātas izstrādājuma izmaksas.

Nozīmīgi ir pētījumi par pucolānu piedevu ietekmi uz cementa hidratācijas procesu, kas ḷauj izprast un spriest par pucolānu ietekmi uz C-S-H veidošanos, betona struktūru, īpašībām [9]. Veicot šādus pētījumus, ir iespējams noteikt optimālās pucolānu piedevas betonam, kuras spēs uzlabot tā īpašības un padarīt to ilgmūžīgāku.

Lai piedevu varētu saukt par pucolānu piedevu, tai ir jāatbilst sekojošām prasībām: tās sastāvā ir jābūt silikātiem vai alumosilikātiem; tās dalı̣nām ir jābūt smalkām, lai tās varētu nodrošināt pietiekoši lielu virsmas laukumu, uz kura tām varētu norisināties cietvielu k্̄īmiskās reakcijas; daḷinām reakcijā ar sārmiem un kalcija hidroksīdu no cementa ir jāveido cementējoši savienojumi (piemēram, kalcija silikāta hidrāts, u. c.).

Pucolānu piedevu pielietošanai betona ražošanā ir sekojošas priekšrocības: samazinātas ekonomiskās izmaksas; palielināta betona stiprība (pucolāni turpina reagèet ar brīvo $\mathrm{Ca}(\mathrm{OH})_{2}$, tādejādi palielinot betona 
stiprību laika gaitā); samazināta ūdens un gāzes caurlaidība (pucolānu reakcijas rezultātā tiek aizpildītas brīvās vietas betona matricā līdz ar to tiek samazināta caurlaidība); palielināta ķīmiskā izturība pret sulfātiem, jūras ūdeni un vājām skābēm; samazināts sarukums (pucolāni samazina nepieciešamo ūdens daudzumu, tādejādi samazinot arī sarukumu, kas rodas izžūstot ūdenim); samazināts hidratācijas siltums (pucolānu reakcijā starp $\mathrm{Ca}(\mathrm{OH})_{2}$ un pucolāniem tiek izdalīts mazāks siltuma daudzums kā rezultātā tiek samazināts termiskais krekings; samazināta sārmusilīcija reakcijas aktivitāte (pucolāni saistās ar sārmiem no cementa, kas citā gadījumā būtu reaǵējoši ar silīcija dioksīdu); l̦oti zema hlorīdu jonu difūzija (pucolāni padara betonu izturīgāku pret jūras ūdens iedarbību) [8]-[10].

Svarīgi ir arī izpētìt dažādu pucolānu piedevu ietekmi uz cementa hidratācijas procesa norisi, vai piedevu ietekme būs labvēlīga un betona īpašības (spiedes stiprība, caurlaidība, ilgmūžība, ksīmiskā izturība u. c.) tiks uzlabotas vai tieši pretēji - pasliktināsies. Hidratācijas procesa izpēte ḷauj noteikt optimālās pucolānu piedevas betonam, kuras atstās labvēlīgu ietekmi uz betona struktūru, ìpašībām un padarīs to ilgmūžīgāku.

Kā pucolāna piedevas izmanto gan dabīgos pucolānus, gan sintētiskos. Veikti plaši pētījumi ražošanas blakusproduktu izmantošanai par cementa aizvietotājam: nano/mikrosilika, biomasas un akmen,ogḷ pelni, stikla pulveris [9], [10].

Pēdējos gadu desmitos, paaugstinoties būvniecības nozares prasībām attiecībā pret betona kvalitāti (mehāniskām un ķīmiskajām īpašībām), ir izveidots jauns betona paveids - augstas izturības betons un īpaši augstas izturības betons (high perfomance concrete - HPC; ultra high perfomance concrete - UHPC). To spiedes stiprība ir lielāka par 120-150 MPa [11]-[13].

Augsta stiprība un elastīgums padara šo materiālu par piemērotu tiltu, dambju, augstceltṇu, kolonu un citu konstrukciju projektēšanā. HPC un UHPC ir raksturīga arī augsta kīmiskā izturība, izcila pretestība dažādiem korozijas veidiem. Tas arī dod iespēju pielietot šo materiālu dažādās konstrukcijās [14].

HPC ir raksturīgs augsts cementa saturs, mikro- un nano-izmēra pildvielas kā arī ķīmiski aktīvās vielas, kas ḷauj variēt ūdens cementa attiecību, paātrināt betona struktūras veidošanos un rezultātā paaugstināt betona k̦īmiskās, mehāniskās, fizikālās īpašības. Smalkām betona sastāvdal̦ām ir liela aktīvā virsma, àtri notiek betona cietēšana - tā rezultātā iegūst homogēnu, blīvu augstas stiprības materiālu [11]-[15].

Viena no betona ķīmiskajām piedevām, kuru pievienojot var samazināt ūdens/cementa attiecību un rezultātā palielināt betona plūstamību un blīvumu, iegūstot augstas stiprības izstrādājumus, ir superplastifikatori [16]. 
Visi superplastifikatori (SP) satur lielmolekulārus, ūdenī šķīstošus polimērus, lielākā daḷa no tiem ir sintētiskas vielas.

Plaši tiek izmantots uz polikarboksilāta ētera bāzes izveidots superplastifikātors Semflow MC.

Betonu ar superplastifikatora piedevu raksturo loti zema porainība. SP daḷiṇu diametrs ir mazāks par 0,5 mm, tās tiek adsorbētas uz cementa daḷin̄ām vai kopā ar citiem smalki dispersiem materiāliem aizpilda tukšumus starp lielākām cementa dal̦iṇām. Rezultātā betona blīvums un izturība palielinās. Izmantojot SP, nepieciešamais ūdens daudzums cietu dalinnu saistīšanai un sablīvēšanai var tikt samazināts līdz 20-30\%.

Tā kā HPC ir raksturīga blīva struktūra, ko nosaka zema ūdens/ cementa attiecība un mikro-, nano-piedevu klātbūtne, perspektīva ir šāda betona pielietošana dažādās ksīmiski agresīvās vidēs [17].

Betona koroziju izraisa agresīvas vielas, kas migrācijas rezultātā nokḷūst betona masā. Korozija ir sairšanas process, ko izsauc k̦īmiskās reakcijas starp materiālu un apkārtējo vidi. Koroziju ievērojami paātrina pastāvīga agresīvo vielu filtrācija cauri betona plaisām un porām [18][20]. Atkarībā no kaitīgo faktoru rakstura, koroziju iedala fizikālajā un ķīmiskajā korozijā, bet praksē šie korozijas veidi summējas.

Ķīmiskā korozija notiek mitruma klātbūtnē. Tās cēloṇi ir dažāda veida agresīvu vielu k̦īmiskā iedarbība uz betona izstrādājumu sastāvdaḷām. Tāpēc ir svarīgs betona blīvums un poru sadalījums, jo no tā ir atkarīga betona necaurlaidība un agresīvu vielu noklūšana betonā.

Īpaši agresīva iedarbība uz betonu ir sulfāta jonus saturošiem šḳīdumiem. Sulfāti ir plaši izplatīti dabā, tie ir arī ražošanas procesu blakusprodukti. To šķīdumi ir spējīgi iesaistīties ḳīmiskajās reakcijās ar savienojumiem, kas ir betona sastāvā, izraisot tilpuma izplešanos, sabrukšanu, atslān,ošanas vai mīkstināšanos un sadalīšanos [21], [22].

Darba uzdevums bija: apkopot pēdējā desmitgadē veiktos pētījumus par dažādu k̦īmiski aktīvo piedevu, superplastifikatoru ietekmi uz betona ar zemu ūdens/cementa attiecību ( $\bar{U} / C)$, mineralogisko sastāvu, mehāniskajām un ksīmiskajām īpašībām; noteikt mineraloǵiskā sastāva, porainības un citu īpašību izmain,as pēc eksponēšanas agresīvos sulfāta jonu saturošos šksīdumos.

\section{Izejmateriāli un metodes}

Tika pētīta cementa pastas mijiedarbība ar dažādām aktīvām piedevām: siliku, nano-siliku, biomasas pelniem, akmen,oglu pelniem, stikla pulveri, ar sola-gela metodi sintezētu amorfu $\mathrm{SiO}_{2}$. Tika izveidoti paraugi 
Betona paraugu ar superplastifikatoru receptes

\begin{tabular}{|c|c|c|c|c|c|}
\hline \multirow{3}{*}{ Materiāls } & \multicolumn{3}{|c|}{ Daudzums, masas\% } & \multirow{3}{*}{$\begin{array}{c}\text { Blīvums, } \\
\mathrm{g} \cdot \mathrm{cm}^{-3}\end{array}$} & \multirow{3}{*}{$\begin{array}{c}\text { Daḷiṇu } \\
\text { diametrs }\end{array}$} \\
\hline & HPC & HPC & HPC & & \\
\hline & 1.0 & 1.5 & 2.5 & & \\
\hline $\begin{array}{c}\text { Cements AAlbourg White } \\
\text { CEM I } 52.5 \mathrm{~N}\end{array}$ & \multicolumn{3}{|c|}{26,43} & 3,15 & $<0,25 \mathrm{~mm}$ \\
\hline Granīts Nybrogrus $A B$ & \multicolumn{3}{|c|}{41,52} & 2,10 & $0-8 \mathrm{~mm}$ \\
\hline Smiltis, SIA SaulkalneS & \multicolumn{3}{|c|}{21,88} & 2,64 & $0-2 \mathrm{~mm}$ \\
\hline $\begin{array}{c}\text { MSP, Elkem-mikrosilica - } \\
920 \mathrm{D}\end{array}$ & \multicolumn{3}{|c|}{4,07} & 2,40 & $0,1-1,0 \mu \mathrm{m}$ \\
\hline Ū/C attiecība & 0.21 & 0.21 & 0.22 & - & - \\
\hline $\begin{array}{l}\text { Superplastifikators } \\
\text { Semflow MC }\end{array}$ & 0.26 & 0.36 & 0.66 & - & $0.1-1.0 \mu \mathrm{m}$ \\
\hline
\end{tabular}

ar dažādu piedevu daudzumu, hidratācijas process tika pētīts pēc 3,7 , 14,28 dienām vai 6 mēnešiem.

Betona īpašību izpētei tika sagatavoti un pētīti vairāku grupu betona maisījuma paraugi ar dažādām piedevām - paraugi ar mainīgu superplastifikatora daudzumu (I. tabula), paraugi ar dažādām ḳīmiski aktīvām piedevām ar pucolāna īpašìbām (II. tabula).

Tika izgatavoti un pētīti betona paraugi ar elektrostaciju pelnu cenosfēru piedevām (mullīta (M) un kvarca (Q)) no uzṇēmuma INOTEK (Krievija).

Lai sasniegtu labākas produkta īpašības un lielāku homogenitāti, izejvielu maisījums tika sagatavots, n,emot vērā izejvielu izmēru sadalījumu, t. i., klasifikācijas līknes. Sausas komponentes nosvēra un samaisīja vienas minūtes laikā. Nākamās minūtes laikā pievienoja $70 \%$ no masas pagatavošanai paredzētā ūdens daudzuma. Samaisīšanas procesā kā pēdējo komponenti pievienoja superplastifikatoru un ķīmiski aktīvo piedevu. Sagatavotos maisījumus ielēja $40 \times 40 \times 160 \mathrm{~mm}$ tērauda formās un sablīvēja uz vibrogalda. Pēc divām dienām paraugus izṇēma no formas un pārvietoja ūdenī boksā, kurā tie tika izturēti 28 dienas, $20{ }^{\circ} \mathrm{C}$ temperatūrā. Lai varētu veikt tālāko izpēti, paraugus pēc 28 dienām gatavināja 2 mēnešus gaisā $\left(\mathrm{T} \sim 20^{\circ} \mathrm{C}\right)$.

Izejvielu un betona ksīmiskā analīze veikta atbilstoši LVS EN 1962:2013 [23], [24].

Ķīmiski aktīvo piedevu pucolāna aktivitāti noteica pēc pielāgotas Costa and Massazza metodes [25], [26]. 
Ūdens un sāls šķīdumu absorbciju noteica atbilstoši LVS EN ISO 15148:2003 [27].

Rentgenfāžu analīzi veica ar Rigaku X-Ray Ultima+ rentgendifraktometrijas iekārtas palīdzību, izmantojot filtrētu vara katoda starojumu $K_{\alpha}$. Pētāmās vielas identificēšanai un kvalitatīvai analīzei izmantoja elektroniskās ICDD datu bāzes (PDF-4+2016, PDF-4/Organics 2016) [28].

Paraugu spiedes stiprības testi tika veikti saskaṇā ar standarta LVS EN 12390-3:2002 prasībām, izmantojot Controls presi [29]. Paraugus vienmērīgi noslogoja, uzturot noteiktu slogošanas ātrumu diapazonā no $0,2 \mathrm{MPa} \cdot \mathrm{s}^{-1} \mathrm{līdz} 1,0 \mathrm{MPa} \cdot \mathrm{s}^{-1}$.

Betona paraugu porainību un poru sadalījumu noteica ar dzīvsudraba porozimetru QUANTACHROME POREMASTER, diapazonā no 0,01 $\mu \mathrm{m}$ līdz $1000 \mu \mathrm{m}$.

Pucolāna materiālu dispersitāti un virsmas laukumu noteica ar BET iekārtu Nova 1200 E-Series, Quantachrome Instruments un lāzera difrakcijas granulometrijas iekārtu CILAS $930 \mathrm{Na \beta}$, mērīšanas diapazons $0,2-500 \mu \mathrm{m}$.

II. tabula

Eksperimentālo betona paraugu recepte ar dažādām pucolāna piedevām

\begin{tabular}{|c|c|c|c|c|c|c|c|}
\hline \multirow[b]{2}{*}{ Materiāls } & \multirow[b]{2}{*}{$\begin{array}{l}\text { Mikro- } \\
\text { silika } \\
E L K E M_{1} \\
30-450 \\
\mathrm{~nm}\end{array}$} & \multirow[b]{2}{*}{$\begin{array}{c}\text { Mikro-/ } \\
\text { nano- silika } \\
\text { ELKEM, } \\
30-450 / 15- \\
100 \mathrm{~nm}\end{array}$} & \multirow[b]{2}{*}{$\begin{array}{c}\text { Amorfs } \\
\mathrm{SiO}_{2} \\
90-100 \mathrm{~nm} \\
\text { vai } \\
\text { (kalcinēts) } \\
590-600 \\
\mathrm{~nm}\end{array}$} & \multirow[b]{2}{*}{$\begin{array}{c}\text { Stikla } \\
\text { pulveris, } \\
50-400 \\
\text { nm }\end{array}$} & \multicolumn{3}{|c|}{ Biomasas pelni } \\
\hline & & & & & $\begin{array}{l}\text { Koka } \\
\text { pelni } \\
<200 \\
\mu \mathrm{m}\end{array}$ & $\begin{array}{l}\text { Koka + } \\
\text { salmu } \\
\text { pelni, } \\
<200 \\
\mu \mathrm{m}\end{array}$ & $\begin{array}{c}\text { Dažādu } \\
\text { salmu } \\
\text { pelni, } \\
<200 \mu \mathrm{m}\end{array}$ \\
\hline $\begin{array}{l}\text { 1. CEMI } 42.5 \mathrm{~N} \\
52.5 \mathrm{R}, \mathrm{kg}\end{array}$ & 950 & 950 & 950 & 950 & 700 & 700 & 700 \\
\hline $\begin{array}{l}\text { 2. Diabass } \\
2 / 5 \mathrm{~mm}, \mathrm{~kg}\end{array}$ & - & - & - & - & 370 & 370 & 370 \\
\hline $\begin{array}{l}\text { 3. Smilts } \\
0.3 / 2.5 \mathrm{~mm}, \mathrm{~kg}\end{array}$ & 470 & 470 & 470 & 470 & - & - & - \\
\hline $\begin{array}{l}\text { 4. Smilts } \\
\text { 0/0.5 mm, kg }\end{array}$ & 200 & 200 & 200 & 200 & 520 & 520 & 520 \\
\hline $\begin{array}{l}\text { 5. Kvarca } \\
\text { pulveris, kg }\end{array}$ & 340 & 340 & 340 & 340 & 300 & 300 & 300 \\
\hline $\begin{array}{l}\text { 6. Pucolāna } \\
\text { materiāls, kg }\end{array}$ & 150 & $140 / 10$ & 140/10 & $140 / 10$ & 210 & 210 & 210 \\
\hline Ū/C attiecība & 0,20 & 0,20 & 0,20 & 0,20 & 0,26 & 0,26 & 0,26 \\
\hline
\end{tabular}


Ķīmisko piedevu mijiedarbības izvērtēšanai izmantoja Furjē transformāciju infrasarkanās spektroskopijas metodi (FTIR), iekārta Shimadzu Prestige-21.

Skenējošo elektronmikroskopijas (SEM) analīzi veica ar mikroskopu HITACHI Tabletop TM-3000 - HisScope.

\section{Eksperimentālā daḷa}

\section{A. Cementa pastas mijiedarbība ar aktīvām piedevām}

Plašākais zinātnisko un eksperimentālo darbu klāsts veltīts dabīgo un mākslīgo pucolāna piedevu un mikro-pildvielu piedevu ietekmes izpētei uz cementa pastas hidratācijas procesu, struktūru un īpašībām [30]-[38]. Pētījumos izmantotas dažādas dispersitātes un ķīmiskā sastāva piedevas: mikro- un nano-silika, ar sola-gela metodi sintezēts amorfais silīcija dioksīds (kalcinēts $500{ }^{\circ} \mathrm{C}$ un nekalcinēts), stikla pulveris, augsti dispersa smilts, pelni - gan elektrostacijas, gan biomasas pelni (koka, miežu salmu, salmu maisījuma pelni), cenosfēras. Piedevas pievienoja no 10 masas $\%$ līdz 40 masas\%.

Pētījumiem, izvēloties piedevas, tika noteikts pucolāna piedevu kīmiskais sastāvs un aktivitāte (III. tabula un IV. tabula).

Visas piedevas raksturo augsts silīcija dioksīda daudzums. Ķīmiskajā analīzē noteikts, ka aktīvā $\mathrm{SiO}_{2}$ daudzums sasniedz 12-13 masas\%.

Rentgenfāžu analīzē noteiktas galvenās kristāliskās fāzes. Biomasas pelnos: kvarcs, kristabolīts un attiecīgie kalcija silikāti - volastonīts un

III. tabula

Pucolāna piedevu kīmiskais sastāvs, masas\%

\begin{tabular}{|c|c|c|c|c|c|c|c|c|}
\hline 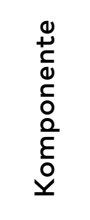 & 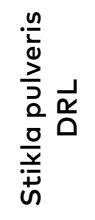 & 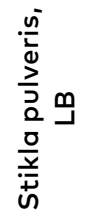 & 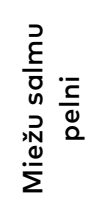 & 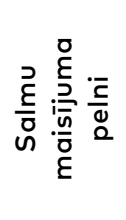 & 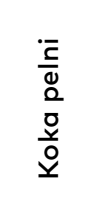 & 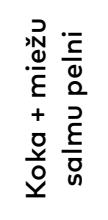 & 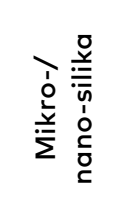 & 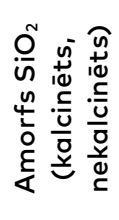 \\
\hline $\mathrm{SiO}_{2}$ & 74,20 & 69,07 & 66,07 & 50,43 & 59,92 & 50,22 & $97 / 99,9$ & $\sim 95$ \\
\hline $\mathrm{PbO}$ & - & 20,02 & - & - & - & - & & \\
\hline $\mathrm{B}_{2} \mathrm{O}_{3}$ & 16,63 & - & - & - & - & - & & \\
\hline $\mathrm{Al}_{2} \mathrm{O}_{3}$ & 1,65 & 1,03 & 5,38 & 3,13 & 4,30 & 4,96 & & \\
\hline $\mathrm{Fe}_{2} \mathrm{O}_{3}$ & 0,16 & 0,19 & 1,78 & 1,20 & 1,60 & 1,84 & & \\
\hline $\mathrm{CaO}$ & 2,09 & 1,39 & 6,06 & 12,47 & 19,89 & 23,28 & & \\
\hline $\mathrm{MgO}$ & - & - & 1,68 & 1,72 & 2,32 & 5,06 & & \\
\hline $\mathrm{Na}_{2} \mathrm{O}$ & 3,82 & 8,02 & 0,24 & 0,17 & 0,37 & 0,37 & & \\
\hline $\mathrm{K}_{2} \mathrm{O}$ & 0,93 & 1,17 & 7,14 & 19,40 & 3,59 & 4,10 & & \\
\hline
\end{tabular}


Cenosfēru k̦īmiskais sastāvs

\begin{tabular}{ccc}
\hline Komponente & mullita $(\mathrm{M})$, masas $\%$ & kvarca (Q), masas\% \\
\hline $\mathrm{SiO}_{2}$ & $55,8 \pm 0,5$ & $61,4 \pm 0,5$ \\
$\mathrm{Al}_{2} \mathrm{O}_{3}$ & $37,9 \pm 0,5$ & $24,4 \pm 0,5$ \\
$\mathrm{Fe}_{2} \mathrm{O}_{3}$ & $1,5 \pm 0,2$ & $3,4 \pm 0,2$ \\
$\mathrm{CaO}$ & $1,9 \pm 0,2$ & $1,9 \pm 0,2$ \\
$\mathrm{MgO}$ & $0,9 \pm 0,2$ & $1,6 \pm 0,2$ \\
$\mathrm{Na} \mathrm{O}_{2}$ & $0,7 \pm 0,1$ & $0,5 \pm 0,1$ \\
$\mathrm{~K}_{2} \mathrm{O}$ & $0,3 \pm 0,1$ & $2,2 \pm 0,1$ \\
\hline Masas zudumi & & \\
\hline $20-400^{\circ} \mathrm{C}$ & $0,5 \pm 0,1$ & $3,9 \pm 0,1$ \\
$400-1000^{\circ} \mathrm{C}$ & 0,1 & 0,2 \\
\hline
\end{tabular}

akermanīts. Mikro- un nano-silika, kā arī ar sola-gela metodi sintezētais $\mathrm{SiO}_{2}$ ir rentgena amorfi. Teorētiski var pieñemt, ka liels amorfās fāzes daudzums norāda uz šo materiālu aktivitāti.

Pētītas kvarcu (Q) un mullītu (M) saturošu cenosfēru īpašības atkarībā no dispersitātes un to mijiedarbība ar cementa pastu.

Balstoties uz kīmiskā sastāva un savienojumu stehiometriskās attiecības datiem, rengenfāžu analīzi un FTIR analīzi, tika noskaidrots, ka Q cenosfērās (kristāliskā fāze kvarcs - $\mathrm{SiO}_{2}$ ) ir ap 37,9 \% brīvā $\mathrm{Al}_{2} \mathrm{O}_{3}$, bet $\mathrm{M}$ cenosfērās (kristāliskā fãze - mullīts $3 \mathrm{Al}_{2} \mathrm{O}_{3} \cdot 2 \mathrm{SiO}_{2}$ ) ir ap $30,5 \%$ brīvā $\mathrm{SiO}_{2}$.

Noteikts, ka gan Q, gan M cenosfēras ir lodveida daḷinas ar dobumiem uz čaulām, kuru iekšienē atrodas vēl mazākas cenosfēras. Gan $Q$, gan M gadījumā cenosfēru malu biezums ir ap 1,1-13,5 $\mu \mathrm{m}$.

Visām pucolāna piedevām tika noteikta aktivitāte.

Pucolāna aktivitāti raksturo kā pucolāna reakciju ar $\mathrm{Ca}(\mathrm{OH})_{2}$, izsakot kā reaǵéjušo CaO daudzumu (masas\%).

Cenosfēru dispersitāte

\begin{tabular}{lccc}
\hline & Bez smalcināšanas & Malts 2 $\mathrm{h}$ & Malts 6 $\mathrm{h}$ \\
\hline Mullīta (M) & MO & M2 & M6 \\
& $7-195 \mu \mathrm{m}$ & $1-70 \mu \mathrm{m}$ & $0,3-12 \mu \mathrm{m}$ \\
\hline \multirow{2}{*}{ Kvarca $(Q)$} & Q0 & Q2 & Q6 \\
& $1-160 \mu \mathrm{m}$ & $0,3-22 \mu \mathrm{m}$ & $0,3-12 \mu \mathrm{m}$ \\
\hline
\end{tabular}


Pucolāna piedevu aktivitāte (reaǵējušā CaO daudzums, masas\%) un īpatnējā virsma

\begin{tabular}{|c|c|c|c|c|c|}
\hline 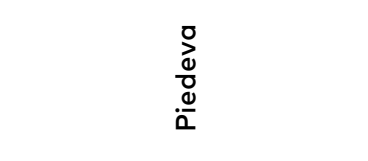 & 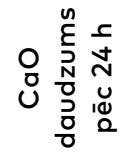 & 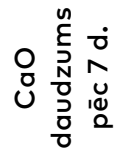 & 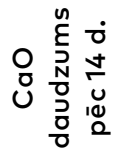 & 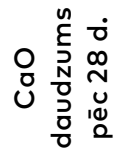 & 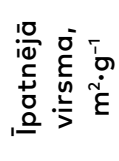 \\
\hline Mikro-silika & 0,0694 & 0,057 & 0,112 & 0,071 & 7,917 \\
\hline Nano-silika & 0,0918 & 0,102 & 0,122 & 0,1004 & 22,025 \\
\hline Koka pelni & 0,050 & 0,0054 & 0,0165 & 0,0012 & 2,869 \\
\hline Salmu pelnu maisījums & 0,005 & 0,0032 & 0,004 & 0,0045 & 3,787 \\
\hline Stikla pulveris LB & 0,09184 & 0,095 & 0,011 & 0,0264 & \\
\hline Stikla pulveris DRL & 0,01568 & 0,0175 & 0,0222 & 0,0206 & \\
\hline Amorfs $\mathrm{SiO}_{2}$ & 3,56 & 7,54 & 12,67 & 13,55 & \\
\hline Kalcinēts $500^{\circ} \mathrm{C} \mathrm{SiO}_{2}$ & 2,79 & 4,23 & 4,86 & 4,697 & \\
\hline Cenosfēras $Q, 0,3-12 \mu \mathrm{m}$ & 1,63 & 5,08 & 7,38 & 7,76 & \\
\hline Cenosfēras $\mathrm{M}, 1,0-80 \mu \mathrm{m}$ & 2,05 & 4,66 & 7,50 & 8,4 & \\
\hline
\end{tabular}

Pucolāna aktivitātes mērījumi parādīja, ka pucolānu reakcijas spēju galvenokārt nosaka aktīvā $\mathrm{SiO}_{2}$ un $\mathrm{Al}_{2} \mathrm{O}_{3}$ daudzums un specifiskais virsmas laukums, t. i., dispersitāte. Literatūrā arī ir norādīts [26], ka pucolāna reakcijas spēja ir atkarīga no $\mathrm{CaO}$ (vai $\mathrm{CaO}$ un $\mathrm{MgO}$ ) tajā, respektīvi $\mathrm{CaO}$ un $\mathrm{SiO}_{2}$ vai $\mathrm{CaO}+\mathrm{MgO}$ un $\mathrm{SiO}_{2}$ attiecības jeb skābes un sārmu oksīdu attiecības.

Augstāko pucolāna aktivitāti visā izpētes periodā (28 dienās) uzrāda ar sola-gela metodi sintezētais amorfais $\mathrm{SiO}_{2}$, kā arī nano-silika. Piedevas ar augstu sārmu oksīdu saturu, miežu salmu pelni un stikla pulveris ir ar nelielu pucolāna aktivitāti.

Abu veidu cenosfēras uzrādīja pucolāna aktivitāti: Q gadījumā labākos rezultātus uzrāda maltie $(0,3-12 \mu \mathrm{m})$ pelni, $\mathrm{M}$ gadījumā labākos rezultātus uzrāda nemaltās $(1,0-80 \mu \mathrm{m})$ cenosfēras.

Rentgenfāžu analīze tika veikta cementa pastas paraugiem bez piedevām, ar mikro-silikas un biomasas piedevām pēc 3, 7, 14 un 28 dienu hidratācijas (1. att., 2. att.). Rentgenogrammā cementa pastai ar mikrosilikas piedevu konstatētas sekojošas kristāliskās fāzes: kalcīts, tobermorìts, haturīts, larnīts, portlandīts un kvarcs. Tobermorīta veidošanās paraugos ar mikro-silikas piedevu novērojama jau pēc 3 dienu hidratācijas, kamēr pārējos cementa pastas paraugos bez piedevām un ar biomasas piedevām tobermorīta veidošanās konstatēta tikai pēc 14 dienu hidratācijas.

Rentgenfāžu analīzē konstatēts, ka paraugiem ar pucolāna piedevām hidratācijas procesa sākumā galvenā kristāliskā fāze ir portlandīts, kas saglabājas visā pētīšanas periodā. Mikro- un nano-silikas piedeva 


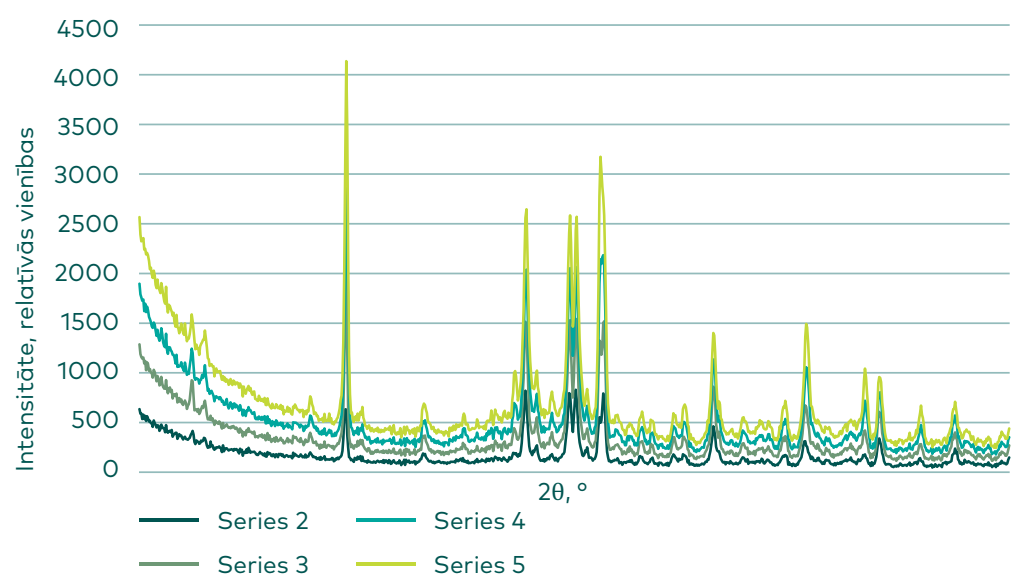

Minerālo saistvielu pētījumi Silikātu materiālu institūtā

1. att. Rentgenogramma cementa pastai pēc: $1-3 ; 2-7 ; 3-14 ; 4-28$ dienu hidratācijas.

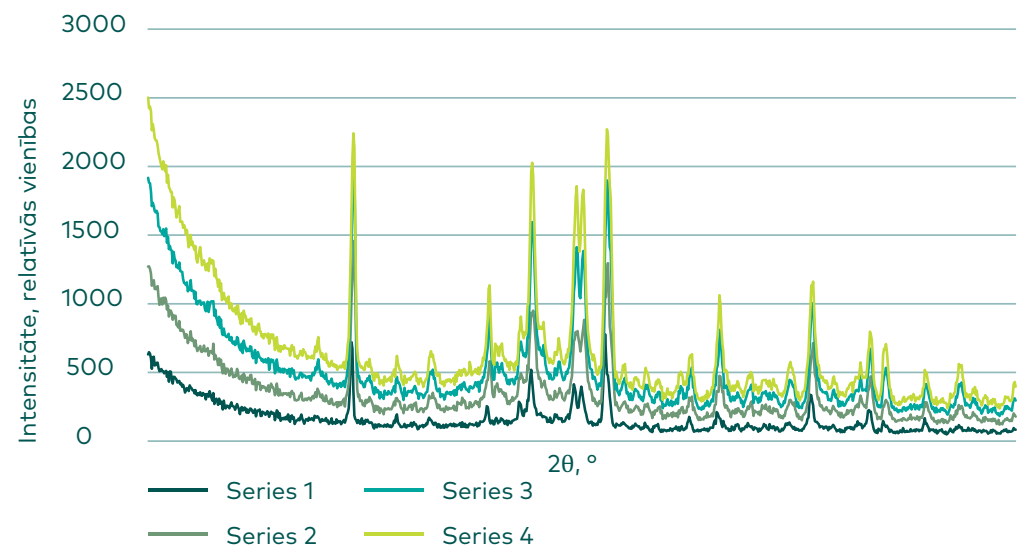

2. att. Rentgenogramma cementa pastai ar mikro-silikas piedevu pēc: 1 - 3; 2 - 7; 3 - 14; 4 - 28 dienu hidratācijas.

veicina kalcija silikāta hidrāta jeb tobermorīta veidošanos jau pēc 3 dienu hidratācijas, skat. VII. tabulu.

Nemaltām (1,0-80 $\mu \mathrm{m}) \mathrm{M}$ cenosfērām pēc to apstrādes ar $\mathrm{Ca}(\mathrm{OH})_{2}$ šķīdumu ar rentgenfāžu analīzi tika konstatēti kalcija alumīnija oksīda hidrāti, kuru klātbūtne liecina par pucolāna reakcijas norisi.

SEM attēli ḷauj izsekot cementa pastas struktūras izmaiṇām atkarībā no hidratācijas laika un piedevu veida.

Pēc 3 dienu hidratācijas paraugu SEM attēlos ir novērojama daḷinu sakopojumu veidošanās; tie varētu būt kalcija silikāta hidrāti. 
Pucolāna piedevu ietekme uz kristālisko fāžu veidošanos atkarībā no hidratācijas laika

\begin{tabular}{|c|c|c|c|c|}
\hline \multirow{2}{*}{ Piedeva } & \multicolumn{4}{|c|}{ Kristāliskā fāze - hidratācijas laiks } \\
\hline & 3 dienas & 7 dienas & 14 dienas & 28 dienas \\
\hline $\begin{array}{l}\text { Koka } \\
\text { pelni }\end{array}$ & $\begin{array}{c}\text { Portlandīts, kalcīts, } \\
\text { haturīts, larnīts, } \\
\text { kvarcs }\end{array}$ & $\begin{array}{c}\text { Portlandīts, kalcīts, } \\
\text { haturīts, larnīts, } \\
\text { kvarcs }\end{array}$ & $\begin{array}{l}\text { Portlandīts, kalcīts, } \\
\text { larnīts, tobermorīts }\end{array}$ & $\begin{array}{l}\text { Portlandīts, kalcīts, } \\
\text { larnīts, tobermorīts }\end{array}$ \\
\hline $\begin{array}{l}\text { Miežu } \\
\text { salmu } \\
\text { pelni }\end{array}$ & $\begin{array}{c}\text { Portlandīts, kalcīts, } \\
\text { haturīts, larnīts, } \\
\text { kvarcs }\end{array}$ & $\begin{array}{c}\text { Portlandīts, kalcīts, } \\
\text { haturīts, larnīts, } \\
\text { kvarcs }\end{array}$ & $\begin{array}{l}\text { Portlandīts, kalcīts, } \\
\text { larnīts, tobermorīts, } \\
\text { kvarcs }\end{array}$ & $\begin{array}{c}\text { Portlandīts, } \\
\text { kalcīts, larnīts, } \\
\text { tobermorīts, kvarcs }\end{array}$ \\
\hline $\begin{array}{l}\text { Mikro- } \\
\text { silika }\end{array}$ & $\begin{array}{l}\text { Portlandīts, kalcīts, } \\
\text { haturīts, larnīts, } \\
\text { kvarcs, tobermorīts }\end{array}$ & $\begin{array}{l}\text { Portlandīts, kalcīts, } \\
\text { haturīts, larnīts, } \\
\text { kvarcs, tobermorīts }\end{array}$ & $\begin{array}{l}\text { Portlandīts, kalcīts, } \\
\text { haturīts, larnīts, } \\
\text { kvarcs, tobermorīts }\end{array}$ & $\begin{array}{c}\text { Portlandīts, kalcīts, } \\
\text { haturīts, larnīts, } \\
\text { kvarcs, tobermorīts }\end{array}$ \\
\hline $\begin{array}{c}\text { Bez } \\
\text { piedevas }\end{array}$ & $\begin{array}{l}\text { Portlandīts, kalcīts, } \\
\text { haturīts, larnīts }\end{array}$ & $\begin{array}{l}\text { Portlandīts, kalcīts, } \\
\text { haturīts, larnīts }\end{array}$ & $\begin{array}{c}\text { Portlandīts, kalcīts, } \\
\text { haturīts, larnīts, } \\
\text { tobermorīts }\end{array}$ & $\begin{array}{c}\text { Portlandīts, kalcīts, } \\
\text { haturīts, larnīts, } \\
\text { tobermorìts }\end{array}$ \\
\hline
\end{tabular}

Cementa pastas paraugā bez piedevām un cementa pastas paraugā ar mikro-silikas piedevu pēc 7 dienu hidratācijas SEM attēlā var ievērot kalcija silikāta hidrātu (C-S-H) veidošanos. Pēc 14 dienām C-S-H klātbūtne ir vērojama visos paraugos, visizteiktāk tas ir redzams cementa pastas paraugā ar mikro-silikas piedevu. Savukārt cementa pastas parauga ar salmu pelnu piedevu SEM attēlā novērojama portlandīta klātbūtne (3. att.).

Pēc 28 dienām hidratācijas process turpinās, SEM attēlos ir redzams C-S-H. Cementa pastas paraugā bez piedevām un paraugā ar salmu pelnu piedevām joprojām ir konstatējama portlandīta klātbūtne. Cementa pastas paraugā, kas kā pucolānu piedevu satur salmu pelnus, novērojama daḷiņu sakopojumu (grupējumu) formēšanās, kas varētu būt C-S-H.

SEM analīze pēc 6 mēnešiem parādīja, ka kalcija hidrosilikātu veidošanās ir turpinājusies, aktīvāk tas ir noticis paraugos ar mikro- un nano-siliku.

Cementa pastas hidratācijas procesa ar cenosfēru piedevām līdz $30 \%$ pētījumi periodā no 3 līdz 28 dienām parādīja, ka dažādas dispersitātes Q cenosfēru ķīmiskā mijiedarbība starp šìm divām komponentēm notiek vāji - iespējamo jaunu kristālisko (kalcija silikātu/aluminātu hidrāti) savienojumu veidošanos var novērot tikai pēc 28 dienām.

Paraugiem ar M cenosfēru piedevu SEM attēli liecina par amorfās daḷas īpatsvara palielināšanos. Pēc 28 dienu hidratācijas paraugu struktūra kḷūst vienmērīgāka, ir novērojama amorfu adatveida savienojumu (kalcija aluminātu hidrātu) veidošanās. 
Darbā iegūtie rezultāti parāda, ka kvarcu saturošās cenosfēras var izmantot kā pildvielu betonam, bet mullītu saturošās cenosfēras - kā Minerālo saistvielu pētījumi Silikātu materiālu institūtā aktīvo pucolāna piedevu.

Lai iegūtu informāciju par cementa pastas hidratācijas procesa norisi, kalcija silikātu hidrāta veidošanos un pucolānu piedevu mijiedarbību ar cementu, tika uzṇemti Furjē transformāciju infrasarkanās spektroskopijas (FTIR) spektri pēc 3, 7, 14 un 28 dienām ar mikro-silikas, koka pelnu,

a

\section{3 dienas}

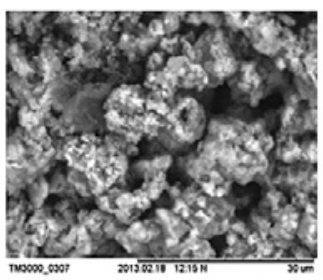

7 dienas

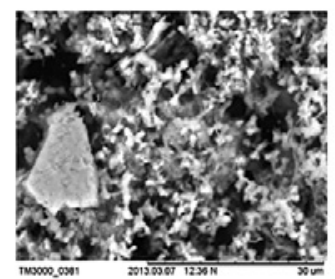

14 dienas
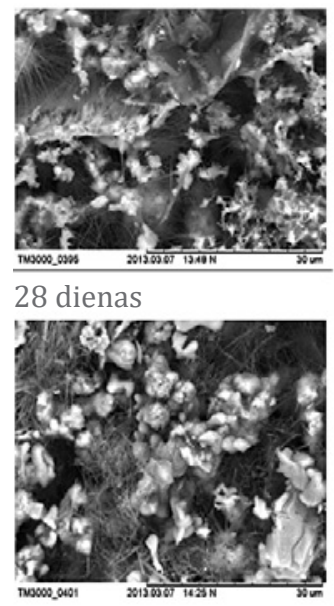

b
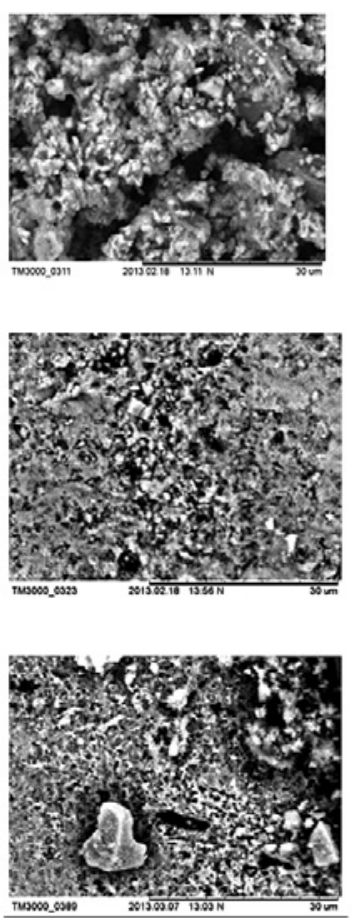

Tu3000_6900

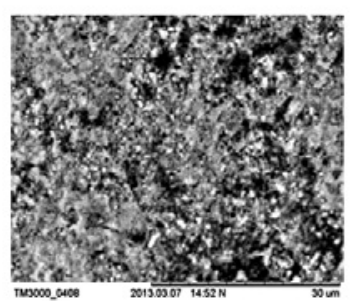

C
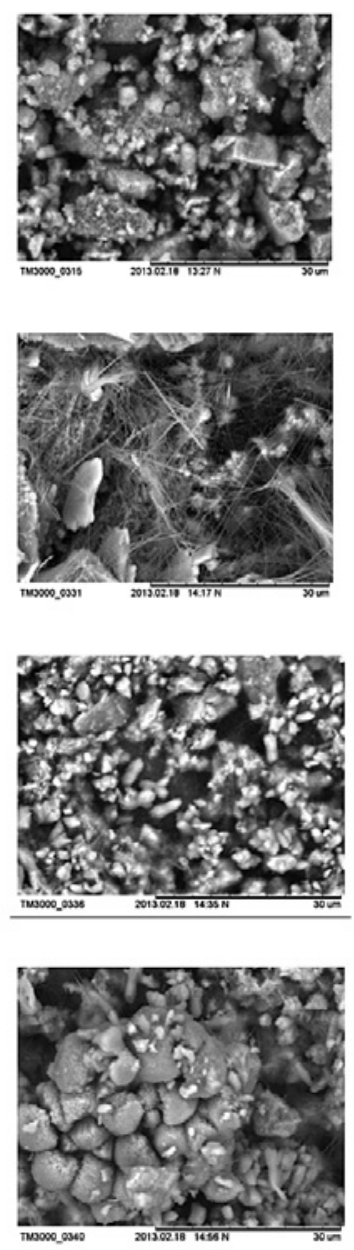

d
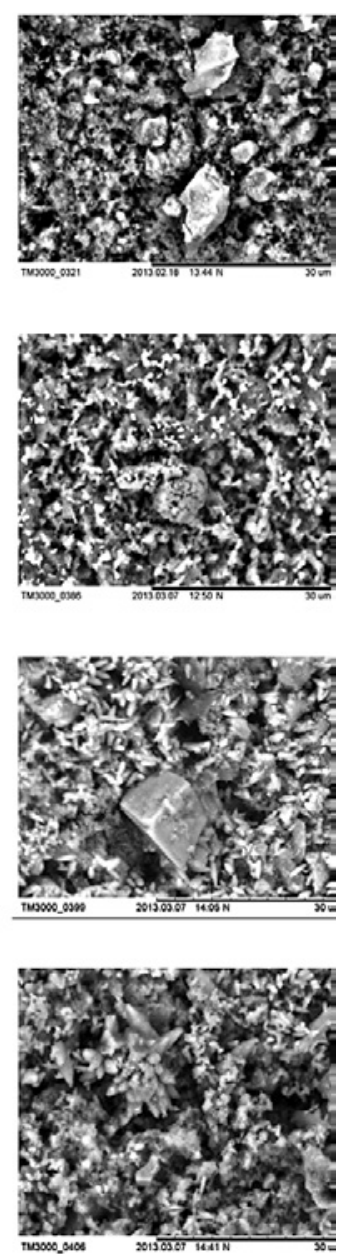

3. att. SEM cementa pastai bez piedevām (A), ar koka pelnu (B), ar salmu maisījuma pelnu (C) un mikro-silikas (D) piedevām pēc 3, 7, 14 un 28 dienu hidratācijas (palielinājums 3000×). 
Q-6 hidratācija 3 dienas

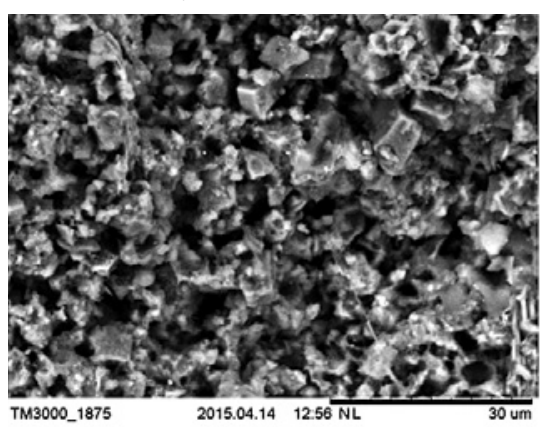

M-6 hidratācija 3 dienas

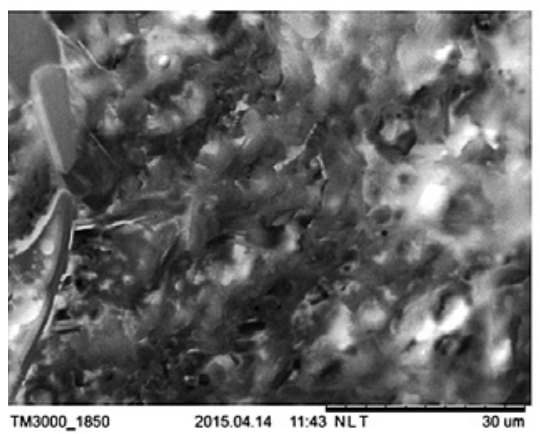

Q-6 hidratācija 28 dienas

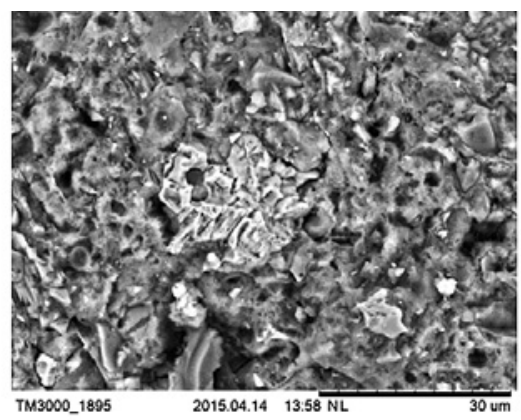

M-6 hidratācija 28 dienas

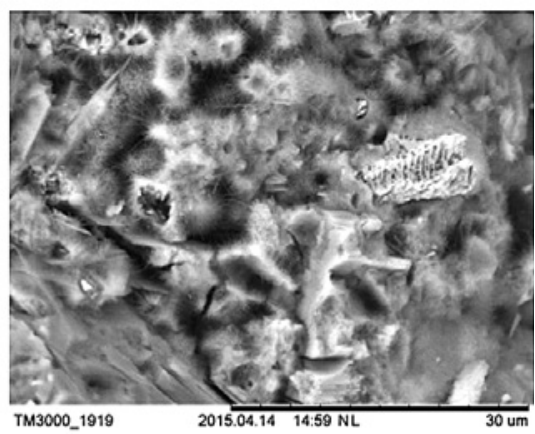

4. att. SEM attēli paraugiem ar $6 \mathrm{~h}$ maltām $Q$ un M cenosfērām.

salmu pelnu, cenosfēru un ar sola-gēla metodi sintezētā amorfā $\mathrm{SiO}_{2}$ piedevām.

FTIR analīzē cementa pastai pēc 3 un 28 dienām ir novērojamas intensīvas $\mathrm{OH}$ grupas absorbcijas joslas pie $3600-3750 \mathrm{~cm}^{-1}$, 5. att. Absorbcijas joslas, kuras konstatētas pie $1400-1480 \mathrm{~cm}^{-1}$ un $870 \mathrm{~cm}^{-1}$ atbilst $\mathrm{CO}_{3}{ }^{2-}$ asimetriskajām svārstībām. Joslas pie $900-1100 \mathrm{~cm}^{-1}$ ir Si-O-Si asimetriskās svārstības agrīnā C-S-H formā. FTIR spektrā ir konstatēta kristāliskā silīcija dioksīda klātbūtne, uz kuru norāda absorbcijas josla pie $670 \mathrm{~cm}^{-1}$. Absorbcijas joslas pie $450-500 \mathrm{~cm}^{-1}$ atbilst $\mathrm{Si}-\mathrm{O}-\mathrm{Si}$ deformācijas svārstībām [40], [41].

Cementa pastai ar piedevām ātrāk parādās absorbcijas maksimumi, kas norāda uz C-S-H klātbūtni.

FTIR analīzē cementa pastai ar koka pelniem vai mikro-/nano-siliku kā pucolāna piedevu pēc 3 un 28 dienām ir novērojamas absorbcijas joslas pie: $1400-1480 \mathrm{~cm}^{-1}$ (atbilst $\mathrm{CO}_{3}{ }^{2-}$ asimetriskajām svārstībām); $1118 \mathrm{~cm}^{-1}$ (atbilst Si-O asimetriskām valences svārstībām [ $\left.\mathrm{SiO}_{4}{ }^{4-}\right]$ tetraedrā); 900-1100 cm-1 (Si-O-Si asimetriskās svārstības agrīnā C-S-H formā); $500 \mathrm{~cm}^{-1}$ (atbilst Si-O-Si deformācijas svārstībām). 
FTIR spektrā cementa pastai ar amorfā $\mathrm{SiO}_{2}$ piedevu pēc 28 dienu hidratācijas ir konstatētas absorbcijas joslas, kuras atbilst Si-O un Si-OH asimetriskām svārstībām. Pie $3387 \mathrm{~cm}^{-1}$ konstatētas absorbcijas joslas, kuras atbilst O-H svārstībām ūdenī un pie $1643 \mathrm{~cm}^{-1}$ konstatētas absorbcijas joslas, kuras atbilst deformācijas svārstībām molekulārā ūdenī. Absorbcijas joslas pie $2939 \mathrm{~cm}^{-1}\left(\mathrm{CH}_{3}\right)$ un $2885 \mathrm{~cm}^{-1}\left(\mathrm{CH}_{2}\right)$ liecina par neizreagēejuša tetraethyl ortosilicate (TEOS) klātbūtni amorfā $\mathrm{SiO}_{2}$ daḷin,ās, skat. 8. att. [40], [41].

Visos FTIR spektros ir novērojams, ka absorbcijas maksimumi, kas saistīti ar Si-O asimetriskām svārstībām, palielinoties hidratācijas laikam, kḷūst intensīvāki. Tas norāda uz kondensācijas procesu.

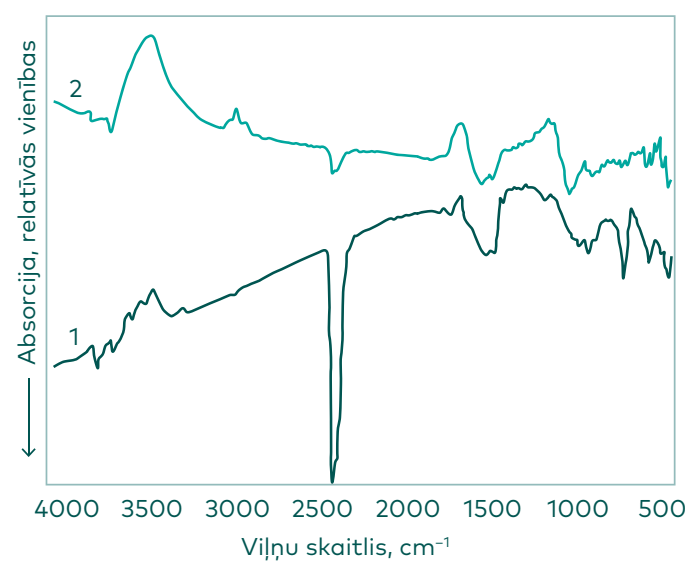

5. att. FTIR spektrs cementa pastai pēc 3 (1), 28 (2) dienām.

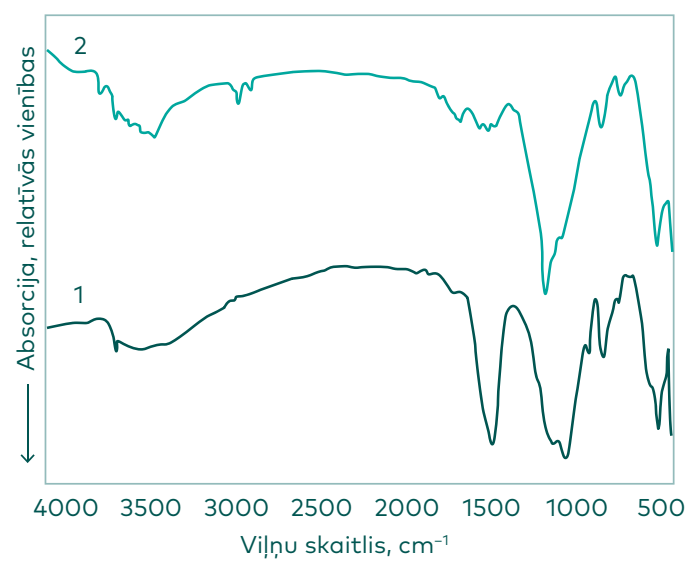

7. att. FTIR spektrs cementa pastai ar nanosilikas piedevu pēc 7 (1) un 28 (2) dienām.

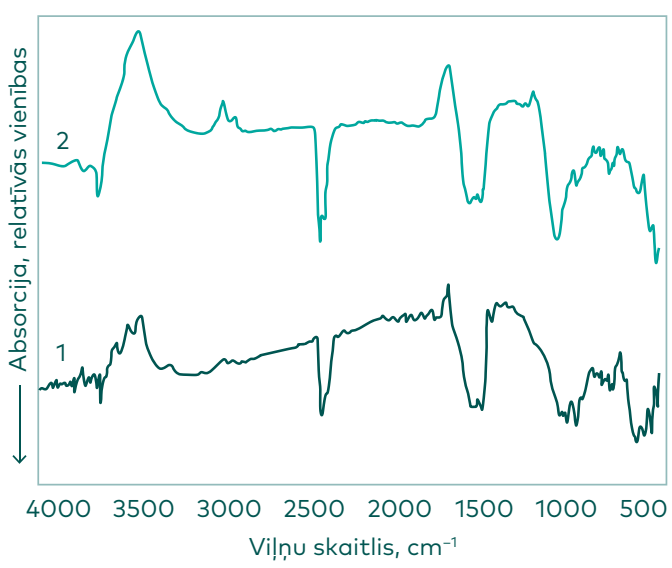

6. att. FTIR spektrs cementa pastai ar koka pelnu piedevu pēc 3 (1), 28 (2) dienām.

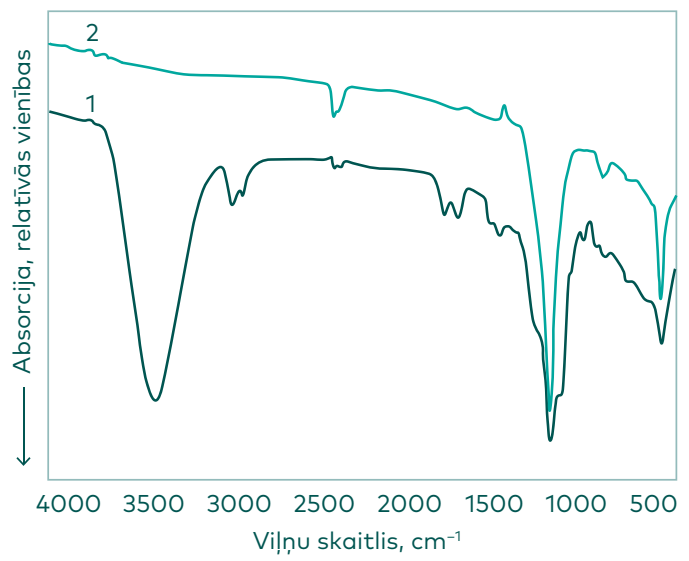

8. att. FTIR spektrs cementa pastai ar amorfa $\mathrm{SiO}_{2}$ piedevu pēc 7 (1) un 28 dienām (2). 
Intensīvākās absorbcijas joslas ir novērojamas, ja kā pucolānu piedevas tiek izmantotas mikro- un nano-silika un ar sola-gēla metodi sintezēts amorfs $\mathrm{SiO}_{2}$.

FTIR analīzē, izvērtējot galveno spektra līniju savstarpējo sakritību, konstatēts, ka cementa pastas paraugos ar pucolāna piedevām hidratācijas procesā norit ortosilikātu [ $\left.\mathrm{SiO}_{4}{ }^{4-}\right]$ kondensācijas process, uz kuru norāda absorbcijas josla pie $1118 \mathrm{~cm}^{-1}$ un kuru apstiprina pucolānu aktivitātes pieaugums paraugu hidratācijas laikā.

Paraugiem ar cenosfēru piedevām ar FTIR tika konstatēts, ka, palielinoties malto $(0,3-12 \mu \mathrm{m}) \mathrm{Q}$ cenosfēru īpatsvaram, cementa pastā pēc 28 dienu hidratācijas pieaug $\mathrm{H}-\mathrm{OH}\left(\sim 3450 \mathrm{~cm}^{-1}\right)$ grupu svārstību un Si-O-Si $\left(\sim 980 \mathrm{~cm}^{-1}\right)$ asimetrisko svārstību agrīnā C-S-H formā intensitāšu maksimumi, kuri norāda uz hidratācijas procesa norisi. Palielinoties hidratācijas laikam, pieaug absorbcijas intensitāte pie $1010 \mathrm{~cm}^{-1}$, kura atbilst Si-O-Si valences svārstībām, kas norāda uz $\mathrm{SiO}_{2}$ savienojumu klātbūtni amorfā formā.

No iegūtajiem datiem izriet, ka Q cenosfēras vairāk darbojas kā telpu aizpildošā pildviela.

\section{B. Augstas stiprības betons (HPC)}

Betona mineraloǵiskais sastāvs, mehāniskās un k,īmiskās īpašības pētītas atkarībā no pievienotā superplastifikatora Semflow MC (SP) daudzuma, ūdens-cementa attiecības, aktīvām k̦īmiskām piedevām, mikropildvielu ķīmiskā sastāva [43]-[48]. Konstatēts, ka pievienotais SP daudzums $(1,0 \%, 1,5 \%, 2,0 \%)$ maz ietekmē betona mineralogisko sastāvu. Galvenās kristāliskās fāzes visos gadījumos ir: kvarcs, tobermorīts, kalcīts, mikroklīns (skat. 9. att.).

Rentgenfāžu analīēe paraugiem ar SP konstatēta likumsakarība palielinoties hidratācijas laikam, samazinās portlandīta daudzums un konstatēta kalcija hidrosilikātu tobermorīta un hilebrandīta veidošanās.

Paaugstinot superplastifikatora daudzumu, betona paraugi kḷūst homogēnāki un blīvāki, paaugstinās blīvums un atbilstoši spiedes stiprība - līdz $154 \mathrm{MPa}$, skat. VIII. tabulu.

VIII. tabula

HPC paraugu spiedes stiprība un blīvums

\begin{tabular}{ccc}
\hline Betona tips & Blīvums, $\mathbf{k g} \cdot \mathrm{m}^{-3}$ & Spiedes stiprība, $\mathbf{M P a}$ \\
\hline HPC 1.0 & 2332,11 & 112,73 \\
\hline HPC 1.5 & 2386,95 & 129,25 \\
\hline HPC 2.5 & 2399,51 & 154,04 \\
\hline
\end{tabular}




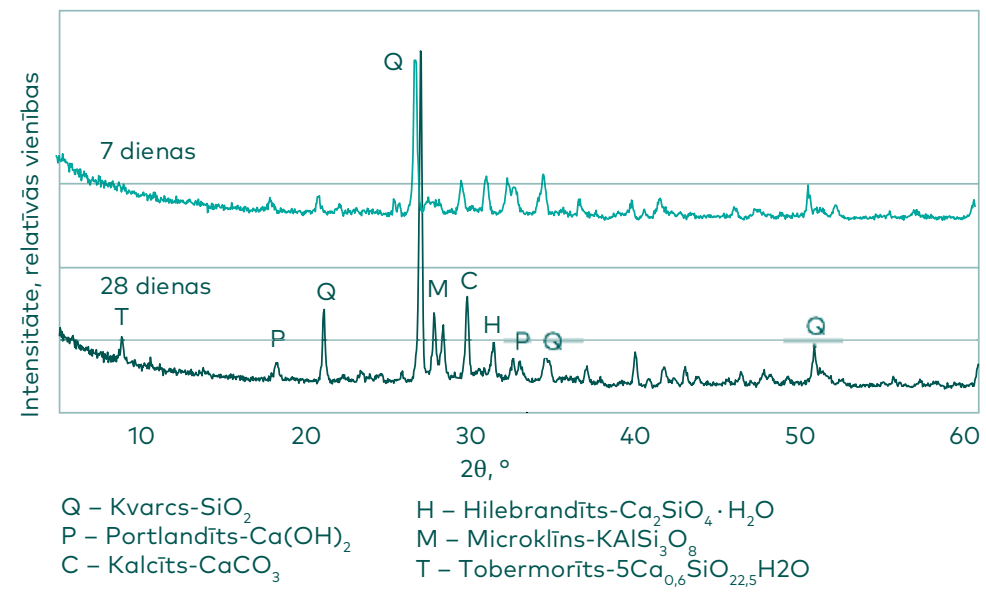

Minerālo saistvielu pētījumi Silikātu materiālu institūtā

9. att. Betona paraugu mineralogiskais sastāvs atkarībā no hidratācijas ilguma.

Porozitāte ir parametrs, kas tieši raksturo materiāla blīvumu un netieši parāda šì materiāla caurlaidību un ķimisko izturību. Poras, kas ir lielākas kā 0,1 $\mu \mathrm{m}$, veicina difūzijas procesu, jonu migrāciju, kapilaritāti, caurlaidību, kamēr mazākas poras nosaka gāzu difūzijas procesu, sorbciju, jonu difūziju un migrāciju.

a

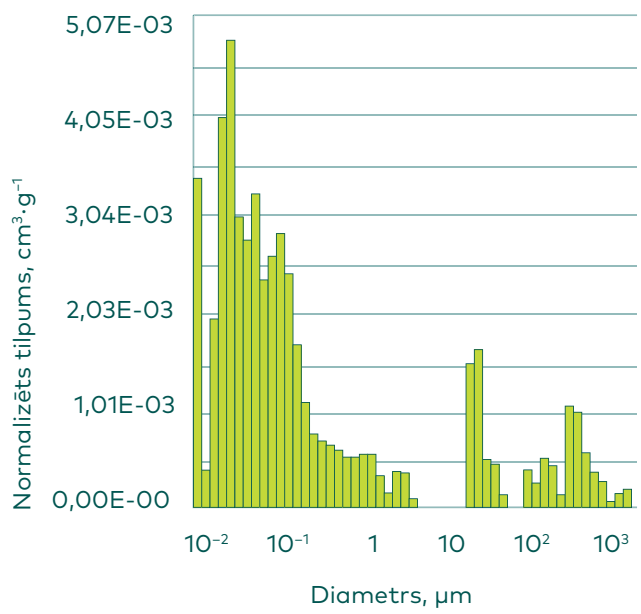

b

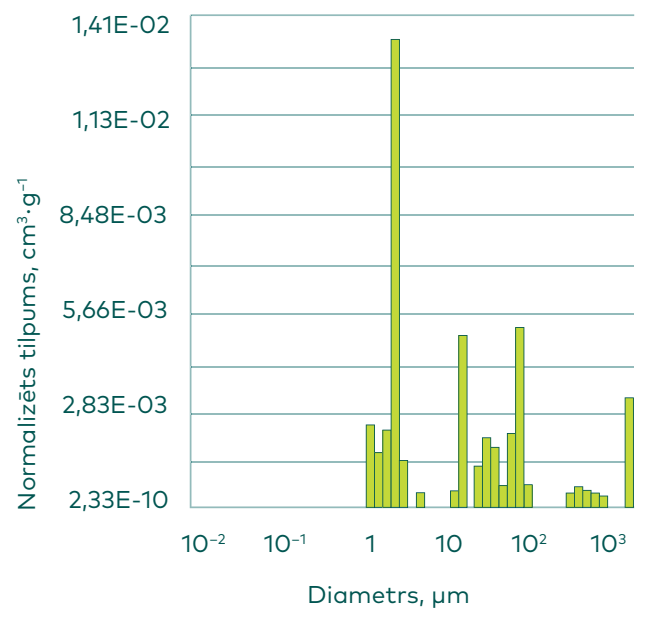

10. att. Poru sadalïjums betona paraugos: $a$ - bez piedevas; $b$ - ar 2,5 \% superplastifikatora. 


\section{Betona korozija}

Betona korozijas procesa izpēte un superplastifikatora un pucolāna piedevas mikro-silikas ietekme uz betona kūmiskās izturības paaugstināšanu tika pētīta, izturot paraugus $\mathrm{H}_{2} \mathrm{O}$ un sulfāta jonu saturošos šḳidumos $\left(0,25 \mathrm{M} \mathrm{H}_{2} \mathrm{SO}_{4}, 0,25 \mathrm{M} \mathrm{Na}_{2} \mathrm{SO}_{4}\right.$ un $\left.0,25 \mathrm{M} \mathrm{MgSO}_{4}\right)$. Betona paraugu eksponēšanas laiks visos šķīdumos - 12 mēneši, ik pēc 30 dienām tika veikta paraugu vizuāla novērtēšana. Betona sastāva recepte parādīta I. tabulā.

Betona paraugu kapilārā $\mathrm{H}_{2} \mathrm{O}$ un sulfāta jonu saturošo šḳīdumu $\left.\left(0,25 \mathrm{M} \mathrm{H}_{2} \mathrm{SO}_{4}, 0,25 \mathrm{M} \mathrm{Na}_{2} \mathrm{SO}_{4} \text { un 0,25 M MgSO}\right)_{4}\right)$ uzsūce noteikta saskaṇā ar augstāk norādīto metodiku. Šksīdumu uzsūce tika izvērtēta atkarībā no pieliktā superplastifikatora daudzuma un sulfātu šksīduma veida. Visos gadījumos maksimālais šķīduma uzsūces laiks bija 120-130 min, turpmāk līknēm "masas pieaugums-laiks" praktiski ir horizontāls raksturs, 11. att.

Šķīdumu uzsūces līknnu raksturs nav atkarīgs no šḳīduma veida, bet ir funkcija no eksponēšanas laika. Pievienotā superplastifikatora daudzums nedaudz ietekmē uzsūktā šķīduma daudzumu, mazāko masas pieaugumu konstatēja paraugiem HPC 2.5 .

Pēc kapilārās uzsūces pārbaudes sulfātu sāḷu šķīdumos uz paraugu virsmas tika novērota sāḷu izkristalizēšanās, kas parāda šķīdumu kapilārās uzsūces ceḷu.

Pēc 12 mēnešu eksponēšanas $\mathrm{Na}_{2} \mathrm{SO}_{4}$ un $\mathrm{MgSO}_{4}$ šķīdumos ar pH = 6 uz betona virsmas netika konstatētas korozijas pazīmes, paraugiem pēc eksponēšanas $\mathrm{MgSO}_{4}$ šķīdumā novērojām tikai sāḷu izkristalizēšanos, t. i., izsālıšanos. Rentgenfāžu analīzē uz virsmas konstatēja kristālisko $\mathrm{MgSO}_{4}$ - epsomìtu.

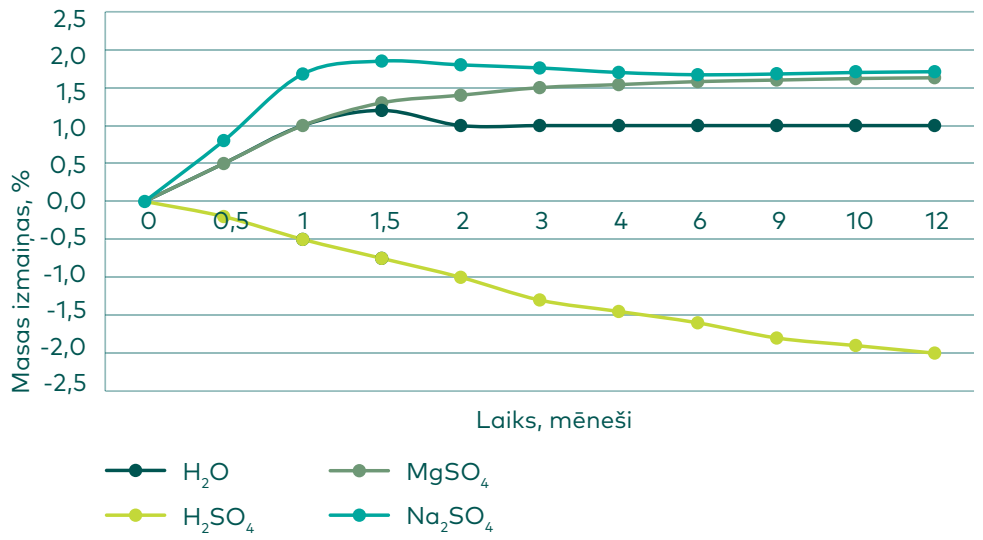

11. att. Masas izmainas dinamika. 
Atšķirīgi rezultāti iegūti paraugiem pēc eksponēšanas sērskābes šķīdumā. Tika konstatēta korozijas radīta heterogēna virsma ar baltu kristālisku nogulšnu plēvīti uz paraugu virsmas. Rentgenfāžu analīzē konstatēts kristāliskas savienojums - gipsis, kas veidojies atbilstoši vienādojumam:

$$
\mathrm{Ca}(\mathrm{OH})_{2}+\mathrm{SO}_{4}^{2-}+2 \mathrm{H}_{2} \mathrm{O} \rightarrow \mathrm{CaSO}_{4} \cdot 2 \mathrm{H}_{2} \mathrm{O}+2 \mathrm{OH}^{-}
$$

No iegūtiem rezultātiem var secināt, ka:

- eksponējot betona paraugus neitrālos šḳidumos pH = 6,0 $\left(\mathrm{H}_{2} \mathrm{O}\right.$, $0,25 \mathrm{M} \mathrm{Na}_{2} \mathrm{SO}_{4}, 0,25 \mathrm{M} \mathrm{MgSO}_{4}$ ), galvenokārt norisinās karbonizācijas un hidratācijas procesi, kas izpaužas kā paraugu masas pieaugums. Pēc izturēšanas ūdenī hidratācijas rezultātā masa pieaug līdz 1,72 \%, bet pēc izturēšanas sāḷu šksīdumos masas pieaugumu galvenokārt nosaka šḳīduma sāḷu kristalizācija uz virsmas un virsmas porās, piemēram, $\mathrm{MgSO}_{4}$ sāḷ šks̄īumā paraugu masas pieaugums - 1,66 \% (sāḷu izkristalizēšanās norāda uz sāḷu difūziju virsmas porās).

- pēc eksponēšanas skābā sulfāta jonus saturošā šḳīdumā notiek mijiedarbība atbilstoši reakcijai (1); sērskābes agresīvās iedarbības rezultātā pieaug $\mathrm{Ca}(\mathrm{OH})_{2}$ skalošanās no betona paraugiem, kas rezultējas kā masas zudumi - 2,04 \%. Pēc 12 mēnešu eksponēšanas iegūstam neitrālu sulfāta jonus saturošu šķīdumu.

Lai noteiktu sulfāta sāḷu škīinumu difūzijas dzil̦umu pēc 12 mēnešu izturēšanas sulfāta jonus saturošos šḳīdumos, HPC 1.5 betona paraugiem tika veikta rentgenfāžu analīze. 12. att. parādītas izpētes vietas, t. i.:

- dzilums 1-2 mm,

- dzilums 10-15 mm,

- dzilums 20-25 mm.

Betona paraugu rentgenogrammās pēc eksponēšanas 0,25 $\mathrm{M} \mathrm{H}_{2} \mathrm{SO}_{4}$ šķīdumā visos gadījumos konstatēti sekojoši kristāliskie savienojumi: kvarcs, portlandīts, kalcīts un kalcija hidrosilikāts - tobermorìts. Pēc 12 mēnešu eksponēšanas sulfāta jonu saturošos šḳīdumos saglabājas betona minerāls tobermorīts, bet šḳīdumu iedarbības rezultātā pēc eksponēšanas vēl konstatēts portlandīts. Iegūtie rentgenfāžu analīzes rezultāti parādīja, ka sulfātu šķīdumi kavē betona minerālu veidošanos, jo pēc 12 mēnešiem vienlaicīgi ar kalcija hidrosilikātu tika konstatēts portlandīts.

Pēc eksponēšanas $\mathrm{Na}_{2} \mathrm{SO}_{4}$ un $\mathrm{MgSO}_{4}$ sāḷu šḳīdumos betonā atbilstošo sāḷu tenardīta vai epsomīta kristalizēšanās nebija konstatēta. Pēc eksponēšanas sērskābes šḳīdumā gipsis konstatēts tikai 1-2 mm dziḷumā. Tas nozīmē, ka iegūtajiem paraugiem ir paaugstināta ķīmiskā izturība pret sulfāta jonus saturošiem šķīdumiem.

Spiedes stiprība betona paraugiem tika mērīta pēc 12 mēnešu eksponēšanas ūdenī un 0,25 $\mathrm{M} \mathrm{H}_{2} \mathrm{SO}_{4}$ šksīdumā. No IX. tabulas datiem redzams, ka pēc 12 mēnešu eksponēšanas ūdenī parauga spiedes stiprība 
Spiedes stiprība pirms un pēc 12 mēnešu eksponēšanas

\begin{tabular}{ccc}
\hline Pirms eksponēšanas, $\mathrm{MPa}$ & $\mathrm{Pēc} 12$ mēnešu eksponēšanas, $\mathrm{MPa}$ \\
\hline & $\mathrm{H}_{2} \mathrm{O}$ & $\mathrm{H}_{2} \mathrm{SO}_{4}$ \\
129,25 & & \\
& 145,26 & 112,70 \\
\hline
\end{tabular}

palielinājās no 129,25 MPa līdz 145,26 MPa. Masas pieaugumu nosaka hidratācijas process, kas turpinās pēc 28 dienu gatavināšanas un kura rezultātā veidojas kalcija hidrosilikāti.

Pēc 12 mēnešu betona paraugu eksponēšanas sērskābes šķīumā paraugu spiedes stiprība samazinās par 12,8 \% - no 129,25 MPa līdz $112,70 \mathrm{MPa}$. Tas ir saistīts ar sērskābes šķiduma agresīvo, korodējošo iedarbību. Korozijas procesa rezultātā paraugs kḷūst poraināks, un spiedes stiprība samazinās.

Betona paraugu korozijas izturības izvērtēšanai svarīgi ir analizēt poru sadalījumu pirms un pēc eksponēšanas sulfātjonu saturošos šksīdumos.

Pēc betona paraugu eksponēšanas sulfātu šķīumos poru lielums un sadalījums mainās plašā diapazonā. Konstatēts, ka paraugos galvenokārt ir sekojoša diametra poras: $6 \cdot 10^{-3}-2 \cdot 10^{-2} \mu \mathrm{m}, 5-20 \mu \mathrm{m}$ un $50-1000 \mu \mathrm{m}$. Vislielāko tilpumu ieñem poras, kuru diametrs atrodas diapazonā $6 \cdot 10^{-3}-2 \cdot 10^{-2} \mu \mathrm{m}$ (sasniedz $1,75 \cdot 10^{-3} \mathrm{~cm}^{3} \cdot \mathrm{g}^{-1}$ ), 13. att.

Porainības rezultāti pēc eksponēšanas sulfāta jonus saturošos šķīidumos ir doti X. tabulā. Kopējā porainība visiem SP saturošiem paraugiem, neskatoties uz šķīdumu korozīvo iedarbību, visos gadījumos samazinās. Tas ir saistīts gan ar noritošiem hidratācijas procesiem, gan ar sāḷu kristalizāciju porās. No tā var spriest, ka betona gatavināšanas process turpinās - tā ir aktīva sistēma. Iegūtie rezultāti parāda, ka pievienojot SP līdz 2,5 \% ir iegūts augstas izturības betons (HPC) - materiāls ar augstu kīmisko izturību, un to var ieteikt pielietošanai konstrukcijās, kur nepieciešama augsta ķīmiskā izturība.

X. tabula HPC 1.5 paraugu kopējā vạẹjā porainība pirms un pēc 12 mēnešu eksponēšanas, \%

\begin{tabular}{ccc}
\hline & Eksponēšanas vide & Pirms eksponēšanas 1,47 \\
\hline Pēc 12 mēnešu & $\mathrm{H}_{2} \mathrm{O}$ & 1,46 \\
eksponēšana dažādās & $0,25 \mathrm{H}_{2} \mathrm{SO}_{4}$ & 1,35 \\
vidēs & $0,25 \mathrm{Na}_{2} \mathrm{SO}_{4}$ & 0,92 \\
& $0,25 \mathrm{MgSO}_{4}$ & 0,89 \\
\hline
\end{tabular}




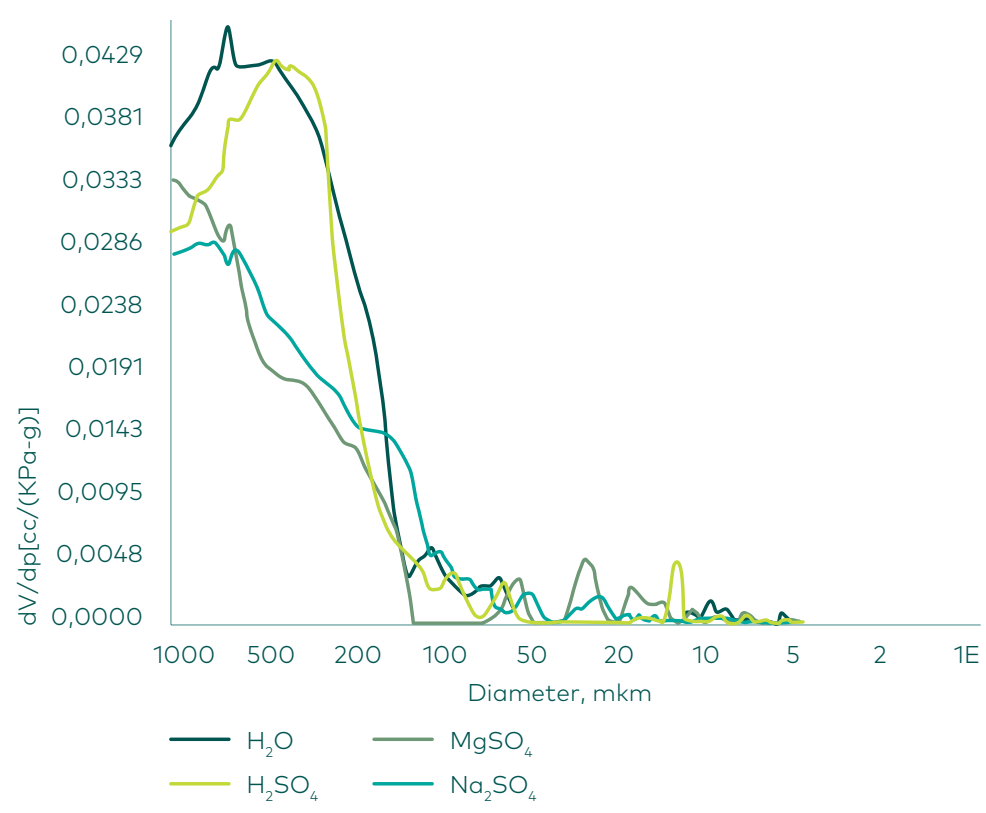

13. att. Poru lielums un sadalījums betona paraugiem pēc eksponēšanas ūdenī un sulfātu šķīdumos.

\section{Secinājumi}

1. Pētītas dabīgo un mākslīgo pucolāna piedevu un mikro-pildvielu piedevu ietekme uz cementa pastas hidratācijas procesu, struktūru un īpašībām. Izmantotas dažādas dispersitātes un kīimiskā sastāva piedevas: mikro- un nano-silika, ar sola-gela metodi sintezēts amorfais silīcija dioksīds (kalcinēts $500^{\circ} \mathrm{C}$ un nekalcinēts), stikla pulveris, augsti dispersa smilts, pelni - gan elektrostacijas gan biomasas pelni (koka, miežu salmu, salmu maisījuma pelni), cenosfēras. Piedevas pievienoja no 10 masas\% līdz 40 masas\%.

2. Rentgenfāžu analīzē konstatēts, ka paraugiem ar pucolāna piedevām hidratācijas procesa sākumā galvenā kristāliskā fāze ir portlandīts, kas saglabājas visā pētīšanas periodā. SEM analīze apstiprina, ka mikro- un nano-silikas piedevas veicina kalcija silikāta hidrāta jeb tobermorīta veidošanos.

3. Cementa pastas ar piedevām hidratācijas procesa pētīšanai izmantota FTIR spektroskopija. Konstatēts, ka visos FTIR spektros absorbcijas maksimumi, kas saistīti ar Si-O asimetriskām svārstībām, palielinoties hidratācijas laikam, kḷūst intensīvāki. Tas norāda uz kondensācijas procesu. Intensīvākās absorbcijas joslas
Minerālo saistvielu pētījumi Silikātu materiālu institūtā 
ir novērojamas, ja kā pucolānu piedevas tiek izmantotas mikro- un nano-silika, ar sola-gēla metodi sintezēts amorfs $\mathrm{SiO}_{2}$.

4. Pucolāna aktivitātes mērījumi parāda, ka pucolāna reakcijas spēju galvenokārt nosaka aktīvā $\mathrm{SiO}_{2}$ un $\mathrm{Al}_{2} \mathrm{O}_{3}$ daudzums un specifiskais virsmas laukums, t. i., dispersitāte. Atkarībā no pucolāna aktivitātes ķīmiskās piedevas var izmantot kā pildvielu betonam, bet, piemēram, mullītu saturošās cenosfēras - kā aktīvo pucolāna piedevu.

5. Pētīts betona mineraloǵiskais sastāvs, mehāniskās un kīmiskās īpašības atkarībā no pievienotā superplastifikatora Semflow MC daudzuma. Iegūti betona paraugi, kuru blīvums un spiedes stiprība atbilst HPC - spiedes stiprība $154 \mathrm{MPa}$.

6. Veikta HPC betona paraugu 12 mēnešu eksponēšana sulfātu jonus saturošos šksīdumos $\left(0,25 \mathrm{M} \mathrm{H}_{2} \mathrm{SO}_{4}, 0,25 \mathrm{M} \mathrm{Na}_{2} \mathrm{SO}_{4}, 0,25 \mathrm{M} \mathrm{MgSO}_{4}\right)$ un konstatēts, ka sulfātu šḳidumi kavē betona minerālu veidošanos. Eksponēšanas šḳīdumu sulfātu sāḷ kristāliskie savienojumi betona paraugos netika konstatēti. Poru daudzums un diametrs pēc eksponēšanas sulfāta jonus saturošos šksīdumos mainās, veidojas vairāk mikroporu $\left(6 \cdot 10^{-3}-1 \cdot 10^{-2} \mu \mathrm{m}\right)$. Spiedes stiprība pēc eksponēšanas sērskābes škīidumā samazinājās.

7. Veiktie pētījumi parāda, ka betona paraugi ar zemu Ū/C attiecību, pucolāna piedevām un SP saturu līdz 2,5 \% pēc mehāniskām un kīimiskām īpašībām atbilst HPC raksturlielumiem un uzrāda augstu ķīmisko izturību sulfāta jonus saturošos šķīdumos.

\section{Pateicības}

Darba izstrādē piedalījušies: bakalaurante Ieva Ose, maǵistranti Veronika Ozoliṇa, Svetlana Kirilova, Jūlija Petrova, Jānis Baroniṇš un Lìga Paušus.

Pētījumi veikti, pateicoties ERAF -projekta "Augstas izturības nanobetons" (No2010/0286/2DP/2.1.1.1.0/10/APIA/VIAA/033) un Valsts pētījumu programmas "Vietējo resursu ilgtspējīga izmantošana jauni produkti un tehnologijas (NATRES un GEO)," apakšprojekta "Jauni keramikas materiāli un tehnologijas" un "Zemes dzīḷu resursu izpēte dabisko izejvielu dažādošanai un jaunu tehnologiju izstrādei" (2010-2017) finansējumam.

\section{LITERATŪRAS SARAKSTS}

[1] F. W. Locher, Cement: Principles of production and use. Düsseldorf, Germany: Verlag Bau+Technik, 2006.

[2] P. C. Hewlett, Ed., Lea's Chemistry of Cement and Concrete. London: Elsevier, 2003. 
[3] X. C. Qiao, C. S. Poon, and C. R. Cheeseman, "Investigation into the stabilization/solidification performance of Portland cement through cement clinker phases," Journal of Hazardous Materials, vol. 139, no. 2, pp. 238243, Jan. 2007. https://doi.org/10.1016/j.jhazmat.2006.06.009

[4] I. A. Chen and M. C. G. Juenger, "Incorporation of waste materials into portland cement clinker synthesized from natural raw materials," Journal of Materials Science, vol. 44, no. 10, pp. 2617-2627, Mar. 2009. https://doi.org/10.1007/s10853-009-3342-x

[5] R. M. Edmeades and P. C. Hewlett, "Cement admixtures," in Lea's Chemistry of Cement and Concrete, P. C. Hewlett, Ed. London: Elsevier, 2003.

[6] V. G. Papadakis and S. Tsimas, "Supplementary cementing materials in concrete," Cement and Concrete Research, vol. 32, no. 10, pp. 1525-1532, Oct. 2002. https://doi.org/10.1016/s0008-8846(02)00827-x

[7] V. G. Batrakov, S. S. Kaprielov, and A. V. Sheinfeld, "Influence of different types of silica fume having varying silica content on the microstructure and properties of concrete," In Proc. Of International conference on fly ash, silica fume, slag and natural pozzolans in concrete, 1992, p. 963.

[8] P. Fidjestol and R. Lewis, "Microsilica as addition," in Lea's Chemistry of Cement and Concrete, P. C. Hewlett, Ed. London: Elsevier, 2003.

[9] A. Korpa and R. Trettin, "The use of synthetic colloidal silica dispersions for making HPC and UHPC systems, preliminary comparison results between colloidal silica dispersions and silica fumes," In Proc. Of International symposium on ultra high performance concrete, 2004, p. 155.

[10] A. R. Pourkhorshidi, M. Najimi, T. Parhizkar, F. Jafarpour, and B. Hillemeier, "Applicability of the standard specifications of ASTM C618 for evaluation of natural pozzolans," Cement and Concrete Composites, vol. 32, no. 10, pp. 794-800, Nov. 2010. https://doi.org/10.1016/j. cemconcomp.2010.08.007

[11] P. Rougeau and B. Borys, "Ultra high performance concrete with ultrafine particles other than silica fume," In Proc. Of International symposium on ultra high performance concrete, 2004, p. 214.

[12] J. Terzijski and J. Odstricilik, "Development and properties of ultra high perfomance concrete (UHPC)". Applied Advanced Materials, p. 63-64, 2008.

[13] S. J. Barnett, J.-F. Lataste, T. Parry, S. G. Millard, and M. N. Soutsos, "Assessment of fibre orientation in ultra high performance fibre reinforced concrete and its effect on flexural strength," Materials and Structures, vol. 43, no. 7, pp. 1009-1023, Oct. 2009. https://doi.org/10.1617/ s11527-009-9562-3

[14] O. Mazanec, D. Lowke, and P. Schießl, "Mixing of high performance concrete: effect of concrete composition and mixing intensity on mixing time," Materials and Structures, vol. 43, no. 3, pp. 357-365, Mar. 2009. https://doi.org/10.1617/s11527-009-9494-y

[15] P.-C. Aïtcin, High Perfomance concrete. London, UK: CRC Press, 1998.

[16] V. Morin, F. Cohen Tenoudji, A. Feylessoufi, and P. Richard, "Superplasticizer effects on setting and structuration mechanisms of 
ultrahigh-performance concrete," Cement and Concrete Research, vol. 31, no. 1, pp. 63-71, Jan. 2001. https://doi.org/10.1016/ s0008-8846(00)00428-2

[17] B. Graybeal and J. Tanesi, "Durability of an Ultrahigh-Performance Concrete," Journal of Materials in Civil Engineering, vol. 19, no. 10, pp. 848-854, Oct. 2007. https://doi.org/10.1061/(asce)0899-1561(2007)19:10(848)

[18] A. Guerrero, M. S. Hernández, and S. Goñi, "The role of the fly ash pozzolanic activity in simulated sulphate radioactive liquid waste," Waste Management, vol. 20, no. 1, pp. 51-58, Feb. 2000. https://doi.org/10.1016/ s0956-053x(99)00300-1

[19] Z. Ahmad, Principles of corrosion engineering and corrosion control. Oxford, UK: Elsevier, 2006.

[20] E. F. Irassar, M. González, and V. Rahhal, "Sulphate resistance of type $\mathrm{V}$ cements with limestone filler and natural pozzolana," Cement and Concrete Composites, vol. 22, no. 5, pp. 361-368, Oct. 2000. https://doi. org/10.1016/s0958-9465(00)00019-6

[21] P. J. Tikalsky, D. Roy, B. Scheetz, and T. Krize, "Redefining cement characteristics for sulfate-resistant Portland cement," Cement and Concrete Research, vol. 32, no. 8, pp. 1239-1246, Aug. 2002. https://doi. org/10.1016/s0008-8846(02)00767-6

[22] M. Eglinton, "Resistance of concrete to destructive agencies," in Lea's Chemistry of Cement and Concrete, P. C. Hewlett, Ed. London: Elsevier, 2003.

[23] International Centre for the Study of the Preservation and Restoration of Cultural Property ICCROM, 2017. [Online]. Available: http://www.iccrom. org. [Accessed: Nov. 10, 2017]

[24] LVS EN 196-2:2013 Method of Testing Cement - Part 2: Chemical Analysis of Cement.

[25] S. Donatello, M. Tyrer, and C. R. Cheeseman, "Comparison of test methods to assess pozzolanic activity," Cement and Concrete Composites, vol. 32, no. 2, pp. 121-127, Feb. 2010. https://doi.org/10.1016/j. cemconcomp.2009.10.008

[26] M. F. Massazza, "Structure of pozzolana and fly-ash and the hydration of pozzolanic and fly-ash cements," In Proc. of the 7th International Congress on the Chemistry of Cements, 1980, pp. 85-91.

[27] EN ISO 15148;2002. Hygrothermal performance of building materials and products - Determination of water absorption coefficient by partial immersion.

[28] D. Popov, R. Dahn, D. Grolimund, P. Pattison, and E. Wieland, "Application of X-ray micro-diffration techniques for characterizing cement materials," In Proc. of 17. Internationale Baustofftagung IBAUSIL, 2009, pp. 931-936.

[29] BS EN 12390-3:2009. Testing hardened concrete. Compressive strength of test specimens.

[30] J. Setina, J. Baroninsh, J. Petrova, and I. Juhnevica, "Influence of Cenospheres on Properties of Cement Paste," In Proc. of 19. Internationale Baustfftagung IBAUSIL, 2015, pp. 526-542. 
[31] L. Krage, D. Bajare, A. Korjakins, J. Setina, I. Juhnevica, and I. Kirilovica, "Studies of the Relationship between Morphology and Pozzolanic Activity of Different Micro Fillers for HPC," Materials Science and Applied Chemistry, vol. 30, p. 28, Sep. 2014. https://doi.org/10.7250/msac.2014.005

[32] J. Setina, V. Akishins, A. Gabrene, and I. Ose, "Latvijas atradnu kvarca smiltis kā pucolāna piedeva betonam," Materials Science and Applied Chemistry, vol. 29, no. 29, p. 69, Feb. 2014. https://doi.org/10.7250/ msac.2013.023

[33] J. Baronins, J. Setina, G. Sahmenko, S. Lagzdina, and A. Shishkin, "Pore Distribution and Water Uptake in a Cenosphere-Cement Paste Composite Material," IOP Conference Series: Materials Science and Engineering, vol. 96, p. 012011, Nov. 2015. https://doi. org/10.1088/1757-899x/96/1/012011

[34] J. Baronins, A. Shishkin, J. Setina, and V. Mironovs, "Influence of Al-W-B Recycled Composite Material on the Properties of High Performance Concrete," Construction Science, vol. 17, no. 1, Jan. 2015. https://doi. org/10.1515/cons-2015-0001

[35] J. Setina, I. Juhnevica, J. Petrova, and J. Baroninsh, "Activity of Mullite and Quartz Containing Fly Ashes," In Abstracts of the Riga Technical University 56th International Scientific Conference, 2015, p. 28.

[36] J. Setina, A. Gabrene, and I. Juhnevica, "Effect of Pozzolanic Additives on Structure and Chemical Durability of Concrete," Procedia Engineering, vol. 57, pp. 1005-1012, 2013. https://doi.org/10.1016/j. proeng.2013.04.127

[37] J. Sētiṇa, J. Petrova, A. Gabrene, and J. Baroniṇš, "Augstas izturības betona mikrostruktūras, mehānisko īpašîbu un ksīmiskās izturības likumsakarības", Materials Science and Applied Chemistry, vol. 27, pp. 43-49, 2013.

[38] J. Setina, L. Krage, I. Juhnevica, T. Skripkina, and G. Sahmenko, "The Influence of Different Pozzolanic Admixtures on Structure and Properties of Concrete," In Proc. of 18. Internationale Baustfftagung IBAUSIL, 2012, pp. 154-161.

[39] J. Setina, L. Krage, D. Bajare, L. Lacere, and I. Rozenstrauha, "Influence of particular types of industrial waste additive to the propertied of Portland cement based mortars," In Proc. of 17. Internationale Baustfftagung IBAUSIL, 2009, pp. 667-671.

[40] M. Y. A. Mollah, M. Kesmez, and D. L. Cocke, "An X-ray diffraction (XRD) and Fourier transform infrared spectroscopic (FT-IR) investigation of the long-term effect on the solidification/stabilization (S/S) of arsenic(V) in Portland cement type-V," Science of The Total Environment, vol. 325, no. 1-3, pp. 255-262, Jun. 2004. https://doi.org/10.1016/j. scitotenv.2003.09.012

[41] T. Richard, L. Mercury, F. Poulet, and L. d' Hendecourt, "Diffuse reflectance infrared Fourier transform spectroscopy as a tool to characterise water in adsorption/confinement situations," Journal of Colloid and Interface Science, vol. 304, no. 1, pp. 125-136, Dec. 2006. https://doi. org/10.1016/j.jcis.2006.08.036 
[42] J. Setina, A. Gabrene, and I. Juhnevica, "Effect of Pozzolanic Additives on Structure and Chemical Durability of Concrete," Procedia Engineering, vol. 57, pp. 1005-1012, 2013. https://doi.org/10.1016/j. proeng.2013.04.127

[43] J. Setina, J. Justs, and G. Sahmenko, "Investigation of Microstructure and Chemical Resistance of High Performance Concrete," In Proc. of International Congress on Durability of Concrete, 2012, pp. 1-8.

[44] J. Setina and S. Kirilova, "Clay Based Poultices for Desalination of Building Materials," Journal of Sustainable Architecture and Civil Engineering, vol. 1, no. 1, Oct. 2012. https://doi.org/10.5755/j01.sace.1.1.2618

[45] J. Setina and S. Kirilova, "Lime Based Mortars for Desalinization of Historical Buildings," In Proc. of 18. Internationale Baustfftagung IBAUSIL, 2012, pp. 1222-1227.

[46] J. Setina, L. Krage, J. Svare, S. Kirilova, "Simulation of desalination processes using lime-based mortars," Chemine Technologija, vol. 50, no. 1, 2009.

[47] L. Krage, D. Bajare, J. Setina, I. Rozenstrauha, and L. Lacere, "Leaching of Heavy Metals from Cement Based Mortars with Waste Additive," In Proc. of International Conference "Advanced Construction", 2008, pp. 201-207.

[48] L. Krage, J. Setina, I. Vitina, V. Ozolina, and L. Lindina, "Corrosion Effect of Different Chloride Salts on Concrete," In Proc. of 16. Internationale Baustfftagung IBAUSIL, 2006, pp. 653-660.

Janīna Sētina, Dr. sc. ing. (1977. g.), Rīgas Politehniskais Institūts (kopš 1992. g. Rīgas Tehniskā universitāte). Darba pieredze: kopš 1972. g. vadošā pētniece un docente Rīgas Tehniskās universitāteses Silikātu materiālu institūtā; kopš 1999. g. Silikātu materiālu testēšanas laboratorijas vadītāja.

135 zinātnisku publikāciju autore, bakalauru, maǵistru un promocijas darbu vadītāja.

E-pasts: janina.setina@rtu.lv

ORCID: 0000-0003-0561-5007

Inna Juhṇeviča, Dr. sc. ing. (2003. g.), Rīgas Tehniskā universitāte. Kopš 1998. g. vinua ir vadošā pētniece un asociētā profesore Rīgas Tehniskā universitātes Silikātu materiālu institūtā.

26 zinātnisku publikāciju autore, bakalauru un maǵistru darbu vadītāja.

E-pasts: inna.juhnevica@rtu.lv

ORCID: 0000-0003-0061-7572

Jānis Baroṇiņ̌š, Mg. chem. (2013. g.), doktorantūras students, Tallinn University of Technology, School of Engineering, Department of Mechanical and Industrial Engineering, Laboratory of Tribology.

11 zinātnisku publikāciju autors.

E-pasts: jbaronins@gmail.com 
Liene Gulbe, Mg. sc. ing. (2015. g.), doktorantūras studente un pētniece Rīgas Tehniskās universitātes Silikātu materiālu institūtā. Viṇas intereses ietver kūimijas tehnoloǵiju un materiālzinātni. 6 zinātnisku publikāciju autore.

E-pasts: liene.gulbe@inbox.lv

Janīna Sētiṇa, Inna Juhṇevica, Jānis Baroniṇš, Liene Gulbe.

\section{Investigation of Mineral Binders in the Institute} of Silicate Materials.

Keywords - binders, concrete, pozzolanic additives, ash, concrete corrosion.

The influence of natural and artificial pozzolanic and micro-filler additives on the cement paste hydration process, structure, properties was studied. Different additives and chemical compositions were used: micro- and nano-silica, amorphous silicon dioxide synthesized by sol-gel method, glass powder, highly disperse sand, different types of ash. The pozzolanic activity of additives mainly depends on quantity and specific surface area, i. e., the dispersity of active $\mathrm{SiO}_{2}$ and $\mathrm{Al}_{2} \mathrm{O}_{3}$. Depending on the pozzolanic activity chemical additives can be used as concrete aggregates or as active additives.

The influence of superplasticizer Semflow MC (SP) on microstructure and properties of concrete was investigated. The compressive strength of concrete with SP increased to $154 \mathrm{MPa}$, corresponding to HPC. The capillary absorption of water and solutions containing sulphate ions into HPC depends on amount of SP. The depth of penetration of solution in the samples decreases consistently by increasing the amount of SP. The formation of crystalline phase during maturation was analysed, and it was found that by increasing testing time the amount of portlandite decreased and calcium hydrosilicate formed. The concrete samples with low W/C ratio, pozzolanic additives and SP up to $2.5 \%$ according mechanical and chemical properties conform to the characteristics of HPC. The investigated concrete has high chemical resistance to solutions containing sulphate ions. 